\title{
Journal of Ecology
}

DR ISABELLE MARÉCHAUX (Orcid ID : 0000-0002-5401-0197)

DR LAWREN SACK (Orcid ID : 0000-0002-7009-7202)

DR JEROME CHAVE (Orcid ID : 0000-0002-7766-1347)

Article type : Research Article

Editor : Pierre Mariotte

Leaf drought tolerance cannot be inferred from classic leaf traits in a tropical rainforest

Isabelle Maréchaux ${ }^{1,2,3}$, Laurent Saint-André ${ }^{4}$, Megan K. Bartlett ${ }^{5,6}$, Lawren Sack ${ }^{6}$, Jérôme Chave ${ }^{2}$

1 AMAP, Univ Montpellier, INRA, IRD, CIRAD, CNRS, F-34000 Montpellier, France

2 Laboratoire Evolution et Diversité Biologique, UMR5174, CNRS, Université Paul Sabatier, IRD, Bâtiment 4R1, 118 route de Narbonne F-31062 Toulouse cedex 9, France

3 AgroParisTech-ENGREF, 19 avenue du Maine, F-75015 Paris, France

4 INRA, UR 1138 BEF, F-54280 Champenoux, France

5 Department of Viticulture and Enology, University of California Davis, 595 Hilgard Lane,

Davis, California 95616, USA

6 Department of Ecology and Evolution, University of California Los Angeles, 621 Charles E.

Young Drive South, Los Angeles, California 90095, USA

This article has been accepted for publication and undergone full peer review but has not been through the copyediting, typesetting, pagination and proofreading process, which may lead to differences between this version and the Version of Record. Please cite this article as doi: 10.1111/1365-2745.13321

This article is protected by copyright. All rights reserved 


\section{Abstract}

1. Plants are enormously diverse in their traits and ecological adaptation, even within given ecosystems, such as tropical rainforests. Accounting for this diversity in vegetation models poses serious challenges. Global plant functional trait databases have highlighted general trait correlations across species that have considerably advanced this research program. However, it remains unclear whether trait correlations found globally hold within communities, and whether they extend to drought tolerance traits.

2. For 134 individual plants spanning a range of sizes and life forms (tree, liana, understory species) within an Amazonian forest, we measured leaf drought tolerance (leaf water potential at turgor loss point, $\pi_{\mathrm{tlp}}$ ), together with 17 leaf traits related to various functions, including leaf economics traits and nutrient composition (leaf mass per area, LMA; and concentrations of $\mathrm{C}, \mathrm{N}, \mathrm{P}, \mathrm{K}, \mathrm{Ca}$, and $\mathrm{Mg}$ per leaf mass and area), leaf area, water use efficiency (carbon isotope ratio), and time-integrated stomatal conductance and carbon assimilation rate per leaf mass and area. We tested trait coordination and the ability to estimate $\pi_{\text {tlp }}$ from the other traits through model selection. Performance and transferability of the best predictive model were assessed through cross-validation.

3. $\pi_{\text {tlp }}$ was positively correlated with leaf area, and with $\mathrm{N}, \mathrm{P}$ and $\mathrm{K}$ concentrations per leaf mass, but not with LMA or any other studied trait. Five axes were needed to account for $>80 \%$ of trait variation, but only three of them explained more variance than expected at random. The best model explained only $30 \%$ of the variation in $\pi_{t \mid p}$, and out-sample predictive performance was variable across life forms or canopy strata, suggesting a limited transferability of the model.

4. Synthesis. We found a weak correlation among leaf drought tolerance and other leaf traits within a forest community. We conclude that higher trait dimensionality than assumed under the leaf economics spectrum may operate among leaves within plant communities, with important implications for species coexistence and responses to changing environmental conditions, and also for the representation of community diversity in vegetation models.

Key words

Functional trait, isotope ratio, leaf economics, leaf mass per area, liana, nutrient concentration, tree, turgor loss point, understory 


\section{Introduction}

Functional traits are measurable quantities related to individual performance and response to environmental conditions (Violle et al., 2007). In plants, efforts to standardize trait measurement protocols have led to global trait databases (Cornelissen et al., 2003; Kattge et al., 2011; PérezHarguindeguy et al., 2013) and the exploration of trait coordination and variation with environment (Chave et al., 2009; Díaz et al., 2016; Reich, Walters, \& Ellsworth, 1997; Wright et al., 2004). A major finding of this research is that, across biomes worldwide, species leaf traits covary, in particular revealing a global trade-off between productive but short-lived leaves with rapid turnover and less productive but more persistent leaves with longer carbon payback (henceforth denoted the leaf economics spectrum, LES; Wright et al., 2004). Other reported trait coordination within or across biomes led to the hypothesis that plants operate along a universal "fast-slow" spectrum (Reich, 2014), encompassing plant strategies related to all resources, including water (Li et al., 2018; Meinzer et al., 2008; Santiago et al., 2004; Zhu et al., 2018), and all plant organs, including stem and roots (Chave et al., 2009; Díaz et al., 2016; Roumet et al., 2016). This formalizes earlier theories suggesting that plant phenotypes correspond to a onedimensional gradient from acquisitive but risky strategies to conservative but safe ones (MacArthur, 1972).

These functional tradeoffs have been transformative in the study of plant strategies by suggesting that the multidimensional plant trait space can be summarized into few well-described dimensions (Hodgson, Wilson, Hunt, Grime, \& Thompson, 1999; Westoby \& Wright, 2006). One major application is the development of new parameterization of land surface models (Lavorel et al., 2007; Prentice et al., 2007). Scheiter, Langan, \& Higgins, (2013) and Sakschewski et al. (2015) used the leaf and wood economics spectra to constrain individual trait combinations in simulations of forest dynamics. The model representation of functional diversity thus improved from a few discrete strategies to a continuum of traits, while eliminating unrealistic trait combinations (Van Bodegom et al., 2012).

In initial studies of the leaf economics spectrum, hydraulic traits have received little attention, in spite of the global significance of vegetation response to drought (Allen et al., 2010; Anderegg et al., 2015). Owing to the scarcity of field-measured drought tolerance traits (O'Brien et al., 2017), modellers proposed to infer plant hydraulic parameters from more easily measured traits such as leaf mass per area (LMA) or wood density (Christoffersen et al. 2016; Xu, Medvigy, Powers, Becknell, \& Guan 2016). However, these studies acknowledge that correlations of 
hydraulic and classical traits are weak, potentially reducing the predictive accuracy and increasing uncertainty in simulations (Christoffersen et al., 2016; Medlyn, De Kauwe, \& Duursma, 2016).

There are several hypotheses for the weakness of these relationships. First, the absence of direct mechanistic link between hydraulic traits and other traits allow them to vary independently from each other in given contexts (Bartlett, Scoffoni, \& Sack, 2012; Blackman, Aspinwall, Resco de Dios, Smith, \& Tissue, 2016; Gleason et al., 2016; Li et al., 2015; Sack et al., 2014). For example, across species within tropical forest communities, xylem drought tolerance, as inferred from xylem water potential at 50\% loss of conductivity, was found to be uncorrelated with wood density (Powell et al., 2017), and leaf drought tolerance, as inferred from leaf water potential at turgor loss point $\left(\pi_{\mathrm{tlp}}\right)$ was decoupled from LMA (Maréchaux et al., 2015).

A second hypothesis for weakness in trait relationships is that trait associations may vary at different scales (Sack et al., 2013). For example, globally established cross-species trait correlations may not hold across individual leaves or individual plants within community or populations (Anderegg et al., 2018; Messier, McGill, Enquist, \& Lechowicz, 2017). Intra-specific variation, which may be associated with plant size, within-canopy variation, or broader environmental gradients, may be comparable or even greater than among-species trait variation (Li, Pei, Kéry, Niklaus, \& Schmid, 2017; Messier, McGill, \& Lechowicz, 2010; Poorter, Castilho, Schietti, Oliveira, \& Costa, 2018; Siefert et al., 2015), and traits can present contrasting sensitivities to these scale-dependent drivers (Messier et al., 2017; Rosas et al., 2019). Intraspecific variation can thus blur interspecific trait relationships, especially when trait values are drawn from independent studies led under various conditions (Clark et al., 2011; Laughlin et al., 2017). As an illustration, accounting for variation in tree size can substantially strengthen trait relationships across species (Medeiros et al., 2019). Overall, higher trait dimensionality than typically assumed under global trait spectra may operate within plant communities, with important implications for species coexistence and responses to changing environmental conditions (Clark, 2010; Laughlin, 2014; Medeiros et al., 2019; Rosas et al., 2019).

We carried out a test of the hypothesis that a leaf drought tolerance trait, the leaf water potential at turgor loss point ( $\pi_{\text {tlp }}$; Bartlett, Scoffoni, \& Sack, 2012), co-varies with and can be predicted from other leaf-level traits within an Amazonian forest. These traits relate to multiple resource use and processes (Table 1), and our dataset covers a diversity of life forms and functions and contrasting microhabitats at the individual level within a tropical forest community. We thus explored trait co-variation as it occurs in the field, without restricting ourselves to potential 
peculiarities of a life form or growth in a common environment (Keenan \& Niinemets, 2016).

We addressed the following specific questions: (i) How do leaf traits co-vary within a tropical forest community? Does $\pi_{\text {tlp }}$ correlate with other leaf functional traits and how does plasticity or intraspecific variability affect these relationships? We hypothesized that $\pi_{\text {tlp }}$ should show stronger relationships with other physiological traits such as carbon assimilation rate, than morphological traits such as LMA (Table 1), with stronger trends when parsing out intraspecific from interspecific variation. (ii) Can leaf traits be combined to robustly estimate $\pi_{\text {tlp }}$ within a diverse community? If so, how transferable would such a predictive model be across life forms or environmental conditions? A high transferability of the model would suggest the model relies on robust mechanistic underpinnings, and vice versa. We hypothesized that a fitted model combining several leaf traits would explain substantial variance in $\pi_{\text {tlp }}$ across plants in our dataset given the wide range of function these traits encompass, and yet hypothesized limited model transferability given the strong context-dependency of many trait-trait relationships.

\section{Material and methods}

Study sites and sampling strategy

Field measurements were conducted at the Nouragues Ecological Research Station in French Guiana, $120 \mathrm{~km}$ south of Cayenne within an undisturbed forest, ca. $50 \mathrm{~km}$ from Cacao, the closest village ( $4^{\circ} 05^{\prime} \mathrm{N}, 52^{\circ} 40^{\prime} \mathrm{W}$; Bongers et al. 2001). The site receives c.a. $3000 \mathrm{~mm} / \mathrm{yr}$ rainfall, with significant seasonal and inter-annual variation due to the movement of the Inter-Tropical Convergence Zone. The wet season lasts from December to July, often interrupted by a short dry period in March, and the dry season generally lasts from the end of August to November with 2-3 months of precipitation $<100 \mathrm{~mm} / \mathrm{mo}$.

Data were collected in May 2014, in the middle of the wet season. In total, we collected mature leaves for 134 individuals, including: 49 canopy trees of 10 species belonging to 7 families, 43 canopy lianas of more than 11 families, 42 understory plants of 12 species ( 27 tree and liana saplings of 6 species, among which 5 were also sampled as canopy individuals, and 15 individuals of 6 understory species representing 3 families). For a subset of the individuals $(n=61)$, we measured the height of leaf sampling. Small branches of canopy plants were collected using the French-spike tree climbing method (Fonderies Lacoste, Excideuil, France; De Castilho et al. 2006) or the single-rope technique (Anderson, Koomjian, French, Altenhoff, \& Luce, 2015).

When part of the foliage of an individual was exposed to direct sunlight, sun leaves were collected 
when possible, otherwise shade leaves were collected. Mature leaves of understory plants were collected at their canopy top. Trees were selected to span contrasting life histories and successional status and maximize variation in leaf drought tolerance (Maréchaux, Bartlett, Gaucher, Sack, \& Chave, 2016). Trees were identified by expert taxonomists. Lianas were identified at the family level, and genus or species level when possible, with the aid of DNA barcoding. DNA was extracted from leaf samples and $r b c \mathrm{~L}$ and matK plastid DNA gene regions were amplified using universal primers and classic protocols, and compared against reference databases (Hollingsworth, Graham, \& Little, 2011).

\section{Leaf trait measurements}

Leaf water potential at turgor loss point ( $\pi_{t \mid p}$, in MPa; Table 1$)$ was measured using a previously published field protocol (Bartlett, Scoffoni, Ardy, et al., 2012). Briefly, a vapour pressure osmometer (Vapro 5520, Wescor, Logan, UT) was used to measure the osmotic potential at full hydration $\left(\pi_{\mathrm{o}}\right) . \pi_{\mathrm{o}}$ was then converted into $\pi_{\text {tlp }}$ using a physically-based calibration relationship, which was further validated at our site (Maréchaux et al., 2016).

Measurements of leaf area (LA, in $\mathrm{cm}^{-2}$; Table 1), leaf mass per area (LMA, in $\mathrm{g} \mathrm{m}^{-2}$ ), and mass-based concentrations of leaf carbon $\left(\mathrm{C}_{\text {mass }}\right.$, in \%), and nutrients (in $\left.\mathrm{mg} \mathrm{g}^{-1}\right)$, including nitrogen $\left(\mathrm{N}_{\text {mass }}\right)$, phosphorus $\left(\mathrm{P}_{\text {mass }}\right)$, potassium $\left(\mathrm{K}_{\text {mass }}\right)$, calcium $\left(\mathrm{Ca}_{\text {mass }}\right)$, and magnesium $\left(\mathrm{Mg}_{\text {mass }}\right)$, and carbon isotope ratio $\left(\delta^{13} \mathrm{C}\right.$, in \%o ) were made for the same leaves or for leaves of the same small branch as $\pi_{\mathrm{tlp}}$, following standardized protocols (Pérez-Harguindeguy et al., 2013). Thick woody petioles were removed and fresh leaves were scanned using a portable scanner (Canon LiDE 60, Canon USA, Lake Success, NY, USA). Leaf area was measured manually from the scans using the ImageJ software (http://imagej.nih.gov/ij/). Leaves were then oven-dried at $65^{\circ} \mathrm{C}$ for $72 \mathrm{~h}$ and weighed, yielding leaf dry mass, from which we calculated LMA (leaf dry mass per unit leaf area). Dry leaves were then ground into a homogeneous powder using a mixer mill (Retsch MM 200, Haan, Germany). $\mathrm{C}_{\text {mass }}, \mathrm{N}_{\text {mass }}$, and $\delta^{13} \mathrm{C}$ were determined using a continuous flow mass spectrometer (Isoprim 100 and Geo-multi-flow, Elementar, Hamburg, Germany). $\delta^{13} \mathrm{C}$ was calculated as:

$$
\delta^{13} \mathrm{C}=\left(\frac{{ }^{13} C /{ }^{12} C}{R_{\text {standard }}}-1\right) \times 100
$$

where $\mathrm{R}_{\text {standard }}$ is the ${ }^{13} \mathrm{C} /{ }^{12} \mathrm{C}$ ratio measured on a V-PDB standard. After mineralisation, $\mathrm{P}_{\text {mass, }}$, $\mathrm{K}_{\text {mass }}, \mathrm{Ca}_{\text {mass }}$ and $\mathrm{Mg}_{\text {mass }}$ were measured by Inductively Coupled Plasma - Atomic Emission 
Spectrometry (ICP-AES, JY 180 Ultrace Jobin-Yvon, France). Nutrient concentrations per leaf area $\left(\mathrm{N}_{\text {area }}, \mathrm{P}_{\text {area }}, \mathrm{K}_{\text {area }}, \mathrm{Ca}_{\text {area }}\right.$, and $\mathrm{Mg}_{\text {area }}$ ) were then obtained by multiplying nutrient concentrations per leaf mass by LMA.

For each sampled leaf, we estimated the time-integrated $\mathrm{CO}_{2}$ assimilation rate per area (

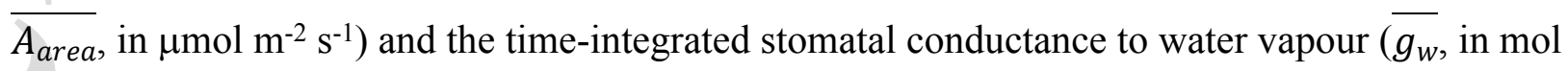
$\mathrm{m}^{-2} \mathrm{~s}^{-1}$ ) using the following approach (Medeiros et al., 2019). A time-integrated estimate of the leaf intercellular $\mathrm{CO}_{2}$ mole fraction, $\overline{c_{i}}$ (in $\mu \mathrm{mol} \mathrm{CO}$ per mole air; $\mu \mathrm{mol} \mathrm{mol}{ }^{-1}$ ), was estimated from leaf $\delta^{13} \mathrm{C}$ using the following relationship: $\overline{c_{i}} / c_{a}=-0.04 \times \delta^{13} C-0.55$ (Cernusak et al., 2013; Farquhar, O'Leary, \& Berry, 1982), with $\mathrm{c}_{\mathrm{a}}$ the atmospheric $\mathrm{CO}_{2}$ concentration taken as 390 ppm. $\overline{A_{\text {area }}}$ was then estimated using the model of Farquhar, von Caemmerer \& Berry (1980) and constant values following Franks, Drake \& Beerling (2009), with the maximum carboxylation capacity and the maximum electron transport rate estimated using $\mathrm{N}$ and $\mathrm{P}$ co-limitation model proposed by Domingues et al. (2010; Figure 7 therein). $\overline{g_{w}}$ was then estimated as

$$
\overline{g_{w}}=1.6 \times \frac{\overline{A_{\text {area }}}}{c_{a}-\overline{c_{i}}}
$$

and $\overline{A_{\text {mass }}}$ (in $\mu \mathrm{mol} \mathrm{g} \mathrm{g}^{-1} \mathrm{~s}^{-1}$ ) was computed by dividing $\overline{A_{\text {area }}}$ by LMA.

\section{Data analysis}

All data analyses were conducted at the individual level. We first tested trait-by-trait correlations among the 18 leaf traits (Table 1) using pairwise Pearson correlation tests on the whole dataset ( $\mathrm{n}=134$ individuals). Second, to assess the dimensionality of the leaf trait space, we conducted a principal component analysis (PCA) on the standardized leaf traits for the whole dataset. We assessed the significance of PCA axes by comparing the axes' eigenvalues with expectations from a broken-stick model following Jackson (1993) and Peres-Neto, Jackson \& Somers (2003). Then, to test whether trait within-canopy plasticity or intra-specific variability can affect the pairwise relationships between $\pi_{\text {tlp }}$ and the other traits, we restricted the dataset to tree species collected at $\geq 5$ canopy heights ( 5 species; 28 individuals). For each trait, we used this subset to fit a linear model with $\pi_{\text {tlp }}$ as the dependent variable and species as factor and/or height of leaf sampling as an additional predictor that could account for contrasting trait variability across the canopy gradient. 
We then tested the ability to predict $\pi_{\text {tlp }}$ from other leaf traits. Using multivariate regressions, we searched for the best model to predict $\pi_{\text {tlp }}$ from the other traits ( $n=134$ individuals). To avoid predictor multicollinearity, we removed traits that exhibited variation inflation factors $(\mathrm{VIFs})>2.0$ (Kutner, Nachtsheim, \& Neter, 2004). The VIF of a given predictor $\mathrm{x}$ is given by $\mathrm{VIF}=1 /\left(1-\mathrm{R}^{2}\right)$, where $\mathrm{R}^{2}$ is the determination coefficient of the regression where the predictor of interest $\mathrm{x}$ is predicted by all the other predictors. We ran the models with all possible combinations of traits as predictors and computed the goodness of fit using the Akaike's Information Criterion corrected for small sample sizes (AICc, Burnham \& Anderson 2003). We estimated the relative 'importance' of each predictor by summing the AICc weights across all the models where the predictor occurs. We selected the model that minimized AICc, choosing the model with fewer predictors in case of a similar performance (differences in model $\mathrm{AICc}<2$ ). Including trait interactions and following the same procedure led to the same selected model. We then quantified model accuracy by computing the in-sample root-mean-square error (RMSE), model consistency and bias by computing the slope and intercept of the linear regression of measured vs. predicted $\pi_{\text {tlp }}$ values (Piñeiro, Perelman, Guerschman, \& Paruelo, 2008), and the fraction of variance uniquely explained by each predictor using commonality analysis, which separates unique and shared effects of predictors (Ray-Mukherjee et al., 2014).

We assessed model out-sample predictive performance through a k-fold random crossvalidation (Olden \& Jackson, 2000): we randomly partitioned the dataset into k equal-sized groups, and withheld one group at a time for validation (here we used $\mathrm{k}=5$ or 10 ). This provided an out-sample RMSE, henceforth denoted $\mathrm{RMSE}_{\mathrm{k} \text {-fold }}$. We repeated this procedure a hundred times and reported the distribution of $\mathrm{RMSE}_{\mathrm{k} \text {-fold. }}$. Finally, we assessed model transferability (also named generality or generalizability) to other datasets through non-random cross-validation (Wenger \& Olden, 2012). Non-random cross-validation involves assigning data to groups that are ecologically, spatially or temporally distinct. In doing so, the heterogeneity in the dataset is taken to be a surrogate for heterogeneity among datasets (Wenger \& Olden, 2012). We used life forms (lianas, trees, understory species) and canopy strata (understory, canopy) as alternative ways to partition the dataset, and this provided RMSE values $\left(\mathrm{RMSE}_{\text {liana }}, \mathrm{RMSE}_{\text {tree }}\right.$ and $\mathrm{RMSE}_{\text {und.sp}}$, with liana, tree and understory species withheld for validation, respectively; and RMSE $\mathrm{und}_{\text {und }}$ and $\mathrm{RMSE}_{\text {canopy, }}$ with canopy and understory individuals withheld for validation, respectively). To avoid the potentially confounding effect of unequal-sized groups when comparing the RMSE across life forms or canopy strata, we randomly sampled individuals in the more numerous groups 
to obtain equal-size groups ( $\mathrm{n}=15$ individuals per group for life forms, and $\mathrm{n}=42$ individuals per group for canopy strata). We repeated this procedure a hundred times and reported the distribution of RMSE values for each life form and canopy strata. As the trees (in the life form partitioning) and the canopy individuals (in the strata partitioning) covered wider ranges of $\pi_{\text {tlp }}$ values than the other life forms or strata respectively (Figs. S2-S3), we also reproduced this analysis by restricting the random sampling of 15 trees or 42 canopy individuals to individuals with $\pi_{\text {tlp }}$ values within the range of the other life forms or strata. In doing so, we aimed to test whether any variability in RMSE values across life forms or strata could be due to contrasting $\pi_{\text {tlp }}$ ranges.

For all analyses, LMA, LA, $\mathrm{N}_{\text {area }}, \overline{g_{w}}, \pi_{\mathrm{tlp}}$, and P, K, Ca, and Mg on a mass and area basis were log-transformed to meet the assumption of normality. For all RMSE computations, predicted $\pi_{\mathrm{tlp}}$ values were back-transformed to arithmetic scale by applying the Baskerville correction factor to account for log-normally distributed errors (Baskerville, 1972). Analyses were conducted using the R software (R Core Team, 2018), and the 'Hmisc' (Harrell \& Dupont, 2015), 'smatr' (Warton, Duursma, Falster, \& Taskinen, 2012), 'ade4' (Dray \& Dufour, 2007), 'car' (Fox \& Weisberg, 2011), and 'MuMIn' (Bartoń, 2015) packages.

\section{Results}

\section{Leaf trait correlation pattern across individuals}

Across the dataset ( $n=134$ individuals), $\pi_{\text {tlp }}$ was statistically linked with leaf size and composition: leaves with more negative $\pi_{\text {tlp }}$ (higher drought tolerance) tended to have lower LA, $\mathrm{N}_{\text {mass }}, \mathrm{P}_{\text {mass }}$ and $\mathrm{K}_{\text {mass }}$ (Table 2, Fig. 1). The relationship of $\pi_{\text {tlp }}$ with LA and $\mathrm{N}_{\text {mass }}$ was however mainly driven by trees, whereas understorey species and trees showed contrasting relationships between $\pi_{\text {tlp }}$ and $\mathrm{K}_{\text {mass }}$ (Fig. 1, Fig. S4). The $\pi_{\mathrm{tlp}}$ was statistically independent of LMA, which across the dataset was intercorrelated with $\mathrm{N}_{\text {mass }}$ and $\mathrm{P}_{\text {mass }}$, with low-LMA leaves tending to show high $\mathrm{N}_{\text {mass }}$ and $\mathrm{P}_{\text {mass }}$ (Table 2). LMA, nutrient concentrations per leaf area, $\delta^{13} \mathrm{C}, \mathrm{C}_{\text {mass }}$ and $\overline{A_{\text {area }}}$ were also pairwise related, with low-LMA leaves tending to present low nutrient concentrations per leaf area and $\overline{A_{\text {area }}}$ as well as low $\mathrm{C}_{\text {mass }}$ and $\delta^{13} \mathrm{C}$ (low water use efficiency). $\mathrm{Ca}_{\text {mass }}$ and $\mathrm{Mg}_{\text {mass }}$ were positively related, and both were negatively with $\mathrm{C}_{\text {mass. }} . \overline{A_{\text {mass }}}$ was positively associated with $\mathrm{LA}$ and $\mathrm{N}$ and $\mathrm{P}$ concentrations both per leaf mass and area.

In the PCA analysis, the three first components explained each more variance than expected from a broken-stick model, explaining altogether $68 \%$ of the total trait variance, and five 
axes were actually needed to account for $>80 \%$ of variance (Table 3 ). The first axis depicted a dimension driven by the tight relationships among LMA and nutrient concentrations per leaf area, $\delta^{13} \mathrm{C}$ and $\overline{A_{\text {area }}}$. The second axis encapsulated the correlations among $\pi_{\mathrm{tlp}}$, LA, and mass-based nutrient concentrations and assimilation rate, whereas the third axis related to the specific coordination between $\mathrm{Ca}$ and $\mathrm{Mg}$ concentrations.

Using the subset of five tree species with at least five different heights of leaf sampling, accounting for a species or height effect in the pairwise relationships between $\pi_{\text {tlp }}$ and the other traits did not explain additional variation, except for $\overline{g_{w}}$ which, after parsing out within- and across-species correlations, appeared weakly positively related to $\pi_{\text {tlp }}$ across species $(\mathrm{P}=0.02$; Fig. S5).

\section{Estimating $\pi_{t p}$ from other leaf traits}

$\mathrm{P}_{\text {area }}, \mathrm{K}_{\text {area }}, \mathrm{Ca}_{\text {area }}, \mathrm{Mg}_{\text {area }}, \overline{A_{\text {area }}}, \mathrm{LMA}, \delta^{13} \mathrm{C}, \mathrm{P}_{\text {mass }}$ and $\mathrm{C}_{\text {mass }}$ were successively removed from the predictors to avoid too strong multicolinearity in the models (VIF $>2$ ). The most important traits to predict $\pi_{\text {tlp }}$ were, in decreasing order, LA, $\mathrm{N}_{\text {mass }}, \mathrm{K}_{\text {mass }}, \mathrm{Ca}_{\text {mass }}, \overline{A_{\text {mass }}}, \overline{g_{w}}$, $\mathrm{Mg}_{\text {mass}}, \mathrm{N}_{\text {area }}$ (with estimated 'importances' of 1.00, 0.97, 0.81, 0.41, 0.28, 0.28, 0.26, 0.26 respectively). Going through the same procedure after removing the pionner trees, which have very large LA, from the dataset led to similar results and the same selected predictors.

The selected model included LA, $\mathrm{N}_{\text {mass }}$ and $\mathrm{K}_{\text {mass }}$, which respectively and uniquely explained $9.2 \%, 5.0 \%$, and $2.6 \%$ of the variation in $\pi_{\text {tlp }}$. The random 5 -fold and 10 -fold crossvalidation produced results close to the model in-sample performance $\left(\mathrm{RMSE}_{5 \text {-fold }}\right.$ and $\mathrm{RMSE}_{10 \text {-fold }}$ narrowly distributed with in-sample RMSE within their range, Table 4, Fig. S6), but the nonrandom cross-validation produced more variable RMSE values across life forms or canopy strata,

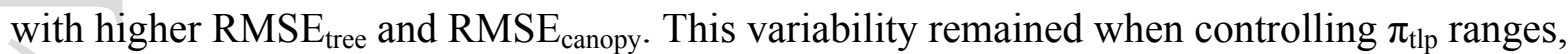
although it was then reduced in the case of the life form partitioning (not shown). The selected models tended to underestimate leaf drought tolerance of most tolerant leaves (Fig. 2), although the fitted line on measured vs. predicted values was not significantly distinct from the 1:1 line in both cases (Fig.2, Table 4).

\section{Discussion}

Weak coordination among leaf traits within a tropical forest community 
We tested coordination among 18 leaf traits related to key functions and resources (Table 1) and measured on individuals of different life forms across the canopy of a diverse Amazonian rainforest. We first explored trait relationships at the scale at which they operate (the organ). We found trait coordination in agreement with a "fast-slow" leaf spectrum (Reich, 2014; Table 1), consistent across life forms and canopy strata (Supporting information Appendix S1). Leaves with lower $\mathrm{N}$ and $\mathrm{P}$ concentrations per leaf mass $\left(\mathrm{N}_{\text {mass }}\right.$ and $\left.\mathrm{P}_{\text {mass }}\right)$ tended to have a higher leaf mass per area (LMA), but also a more negative leaf water potential at turgor loss point $\left(\pi_{\mathrm{tlp}}\right)$. This partly extends to drought tolerance previously reported economic trait coordination across tropical tree species (Baltzer \& Thomas, 2010; Baraloto et al., 2010; Fortunel, Fine, \& Baraloto, 2012; Patiño et al., 2012; Santiago \& Wright, 2007; Zhu et al., 2018). This is in agreement with previous results at our site showing that $\pi_{\mathrm{tlp}}$ varied with species successional status, early successional species having a less negative $\pi_{\mathrm{tlp}}$ than late successional ones (Maréchaux et al., 2016). The fact that Powell et al. (2017) found no relationship between $\pi_{\text {tlp }}$ and wood density is consistent with the fact that the wood economic spectrum and the leaf economic spectrum are independent in tropical rainforests (Baraloto et al., 2010), e.g., some light-demanding species with acquisitive leaves may have a relatively dense wood, and shade tolerant species with conservative leaves may have a relatively light wood.

However, the relationships in agreement with a leaf "fast-slow" spectrum in our dataset left the majority of trait variance unexplained. No fewer than five dimensions were needed to encapsulate $>80 \%$ of trait variation, and only three of them explained more variance than expected from a random pattern. Specifically, $\pi_{\text {tlp }}$ and LMA were not correlated, in agreement with previous studies (Bartlett, Scoffoni, \& Sack, 2012; Esperón-Rodríguez et al., 2018; Maréchaux et al., 2015). It has been argued that the strength of leaf economics trait relationships depends on trait ranges, which should decrease at smaller spatial scales (Funk \& Cornwell, 2013; Messier et al., 2017), and this could explain the weaker coordination among leaf traits at local scale than at regional or global scale. However, our sampling encompassed a diversity of plant species covering a large taxonomic breadth and leaves displaying a substantial variability in trait values. Overall, our dataset gathered at a single site of Amazonia spans a large fraction of the reported global leaf trait variation. Indeed, $\mathrm{N}_{\text {mass }}$ and $\mathrm{P}_{\text {mass }}$ ranged from $0.75 \%$ to $3.93 \%$ and from 0.03 to $0.20 \%$, respectively, LMA varied from 28 to $398 \mathrm{~g} \mathrm{~m}^{-2}$, and $\pi_{\mathrm{tlp}}$ from -2.73 to $-1.06 \mathrm{MPa}$ in our dataset, which are substantial in comparison with respective $95 \%$ ranges in global plant trait databases, i.e., $0.8-3.9 \%$ and $0.04-0.35 \%$ for $\mathrm{N}_{\text {mass }}$ and $\mathrm{P}_{\text {mass }}, 21-222 \mathrm{~g} \mathrm{~m}^{-2}$ for LMA (Kattge et al., 2011), 
and -3.44 to -1.00 MPa for $\pi_{\text {tlp }}$ (Bartlett, Scoffoni, \& Sack, 2012).

Alternatively, the weak coordination among traits in our dataset may have arisen from trait plasticity (Anderegg et al., 2018; Laughlin et al., 2017; Li et al., 2017; Niinemets, Keenan, \& Hallik, 2015). Our sampling was designed to span a large range of leaf functional diversity at our site, and leaves were collected from shaded understory to top canopy. Environmental plasticity may thus add to genetic variation in leaf traits. Indeed, several traits, such as LMA or $\delta^{13} \mathrm{C}$, varied with canopy leaf height (Appendix S1) as previously documented for these traits along the vegetation depth gradient, or equivalently light intensity (Domingues, Berry, Martinelli, Ometto, \& Ehleringer, 2005; Keenan \& Niinemets, 2016; Niinemets, Keenan, \& Hallik, 2015; Ometto et al., 2006). In contrast, other traits such as $K_{\text {mass }}$ or $\pi_{\text {tlp }}$ did not vary with leaf height in our dataset (Appendix S1; Maréchaux et al., 2016). These contrasted relationships with vertical environmental gradient across traits can weaken the relationships among traits in our dataset (Messier et al., 2017). Thus, trait coordinations were stronger when we restricted our analysis to understory plants (Appendix S1), which thrive in a more homogeneous environment. However, explicitly accounting for height effect or intra-specific variation in our dataset did not reveal any additional relationship between $\pi_{\text {tlp }}$ and the other traits, except for the time-integrated stomatal conductance which then showed a weak positive relationship with $\pi_{\text {tlp }}$ across species, as expected under a "fastslow" spectrum (Table 1, Medeiros et al., 2019). Although a more in-depth sampling would allow to better disentangle any potential scale effect on trait covariation in the future (Anderegg et al., 2018; Li et al., 2017; Medeiros et al., 2019; Messier et al., 2017), our results thus suggest that leaf traits within a tropical forest community vary across a higher-dimensional space than often assumed. As a result, care should be taken when interpreting variation in one trait as a proxy of individual integrated ecological strategies according to spectra observed at higher scales.

As opposed to our sampling, previous trait sampling protocols often attempted to minimize trait variation due to environment and focused exclusively on leaves exposed to high-light conditions (Asner et al., 2014; Pérez-Harguindeguy et al., 2013; but see e.g. Li et al., 2017). However, in doing so, the majority of leaves within a forest canopy and an important diversity of plants and species within forest communities are being overlooked (Keenan \& Niinemets, 2016). If trait coordination is to be used to explore the drivers of community assembly and ecosystem functioning, trait-based studies should encompass the diverse light conditions and plant life forms that occurred locally. More in-depth sampling of multiple trait variation across forest microenvironmental conditions is needed to further identify the multiple drivers that can entangle 
themselves in shaping observed trait co-variation patterns across individuals.

\section{On attempting to predict leaf drought tolerance based on other leaf traits}

Statistical models may be used to estimate some unmeasured trait values from measured ones, thus facilitating the parameterization of multiple processes for a diversity of plants in vegetation models. Several studies hence proposed to estimate species hydraulic traits such as $\pi_{\text {tlp }}$ from other traits such as LMA and wood density, based on relationships obtained through global metaanalyses on species means (Christoffersen et al., 2016; Xu et al., 2016). Intra-specific variability may have weakened these relationships established using trait values drawn from independent sources (Patiño et al., 2012). Although the 18 leaf traits of our dataset were measured on the same leaves and encompassed a range of functions, the best model of $\pi_{\text {tlp }}$ based on the other traits explained no more than $30 \%$ of $\pi_{\text {tlp }}$ variation. Additionally, out-sample predictive performance varied across life forms or canopy strata, suggesting a limited transferability of such model. This may evidence the lack of direct mechanistic links between $\pi_{\text {tlp }}$ and the selected predictors, namely leaf area, nitrogen and potassium concentrations per leaf mass.

Leaf area displays a wide variation across species globally (Wright et al., 2017), as in our dataset gathered within a tropical forest community, where it was the most important predictor of $\pi_{\mathrm{tlp}}$. More drought tolerant leaves tended to be smaller than others, a trend that remained after removing pioneer trees that had a particularly high leaf area. Such a relationship is in agreement with expectations under a "fast-slow" spectrum. Displaying larger leaves allow a high light interception at lower twig construction cost, which, all else being equal, can confer a growth advantage (Wright, Falster, Pickup, \& Westoby, 2006). At the same time, larger leaves typically have major veins of larger diameter (Sack et al., 2012), providing the water transport capacity to cool the leaves through transpiration and compensate for their thicker boundary layer when water supply is not limited (Wright et al., 2017). This is however at the cost of leaf hydraulic safety under water stress, which has been found to be greater in smaller leaves with a higher density of smaller veins (Scoffoni, Rawls, McKown, Cochard, \& Sack, 2011). In agreement with our findings, Medeiros et al. (2019) did find a positive relationship between leaf area and $\pi_{\text {tlp }}$ across species within a lowland dry forest. In contrast, leaf area and $\pi_{\mathrm{tlp}}$ were found to be unrelated across species within a wet montane forest (Medeiros et al., 2019) and across species ranging strongly in drought tolerance and native habitat (Scoffoni et al., 2011), suggesting the coordination between leaf area and $\pi_{\mathrm{tlp}}$ is context-dependant. Similarly, and more generally, correlations between 
hydraulic traits, such as $\pi_{\text {tlp }}$, and economic traits, such as $\mathrm{N}_{\text {mass }}$, varied across studies, with some finding significant relationships (Medeiros et al., 2019; Rosas et al., 2019; Zhu et al., 2018), while others finding no relationship (Bartlett et al., 2016; De Guzman, Santiago, Schnitzer, \& ÁlvarezCansino, 2017; Li et al., 2015; Medeiros et al., 2019; Rosas et al., 2019).

Potassium activates many enzymes that are essential for photosynthesis and respiration and is also important for stomatal control (Roelfsema \& Hedrich, 2005), which could explain its association with leaf economic traits in our dataset and in previous studies (Baraloto et al., 2010; Fyllas et al., 2009; Wright et al., 2005). Wright et al. (2005) argued that K concentration should be more tightly associated with other cation concentrations such as $\mathrm{Ca}$ and $\mathrm{Mg}$ than with classic economic traits, since they mediate together many key metabolic processes within the leaf, such as stomatal conductance and cell wall development (Garten, 1976). Although Patiño et al. (2012) did find a stronger association among leaf cation concentrations than with economic traits for tropical trees, $\mathrm{K}$ concentration was not related to $\mathrm{Ca}$ or $\mathrm{Mg}$ concentrations in our dataset. Patiño et al. (2012) further hypothesized that higher cation concentration values would contribute to lowering leaf osmotic potentials through accumulation of osmotically-active solutes (Leigh \& Wyn Jones, 1984; Olivares \& Medina, 1992), and this would result in more negative $\pi_{\text {tlp }}$ and more drought tolerant leaves (Bartlett, Scoffoni, \& Sack, 2012). But we here found an opposite positive trend between bulk K concentration per leaf mass and $\pi_{\text {tlp. }}$. This relationship could be indirectly driven by stomatal function, as $\mathrm{K}$ contributes to stomatal control and a less negative $\pi_{\text {tlp }}$ is associated with earlier stomatal closure (Hochberg, Rockwell, Holbrook, \& Cochard, 2018; Martin-StPaul, Delzon, \& Cochard, 2017; Meinzer et al., 2016), although $\mathrm{K}$ is involved in a range of other processes within the leaf. Overall, the correlation between $\mathrm{K}$ concentration and $\pi_{\mathrm{tlp}}$ is not straightforward, varied across life forms in our dataset (Fig. 1), and was weak overall: if leaves with high $\mathrm{K}$ concentrations all tended to be at the less drought tolerant side of our dataset gradient, leaves with low $\mathrm{K}$ concentrations had $\pi_{\text {tlp }}$ values encompassing the whole gradient.

Leaf and wood economic spectra are typically independent in tropical forests (Baraloto et al., 2010; Díaz et al., 2016; Fortunel et al., 2012), so it can a priori make sense to use leaf traits exclusively to predict another leaf trait. However, hydraulic functions may be more integrated through plant organs than carbon economy. Indeed, several studies reported a coordination of hydraulic traits across plant organs in some tropical forest sites (Li et al., 2018; Meinzer, Johnson, Lachenbruch, McCulloh, \& Woodruff, 2009; Meinzer et al., 2008; Nolf et al., 2015) and in global syntheses (Bartlett, Klein, Jansen, Choat, \& Sack, 2016). Other hydraulic traits than $\pi_{\text {tlp }}$ are 
however difficult or long to measure in the field, or prone to artefact measurements in tropical plants (Cochard et al., 2013), and thus remain under-documented in tropical forest communities (Bartlett et al., 2016; Choat et al., 2012). Together with our results, this calls for more direct measurements of $\pi_{\mathrm{tlp}}$ and other physiological traits, especially in tropical forests (Blackman, 2018; Brodribb, 2017; Griffin-Nolan et al., 2018; Paine, Deasey, \& Duthie, 2018; Yang, Cao, \& Swenson, 2018).

\section{Conclusions}

Our results illustrate that the integration of traits across function within plant communities can be weaker than assumed according to globally established trait spectra across species. Using global spectra to constrain plant trait combinations in vegetation models may thus result in overlooking some existing trait combinations and simulating communities that occupy a narrower trait space than actually observed in situ (Asner, Knapp, Anderson, Martin, \& Vaughn, 2016; Laughlin, 2014; Li et al., 2015). This may hinder models' ability to robustly simulate ecosystem functioning (Cardinale et al., 2009; Mokany et al., 2016). In absence of clear mechanistic links, the strength of between-trait correlations is context-dependent. Disentangling hard biophysical constraints from context-dependent selection in shaping empirically observed trait covarition is important to understand and predict community diversity and ecosystem functioning.

\section{Acknowledgements}

We thank Valentine Alt, Patrick Châtelet, Samuel Counil, and Philippe Gaucher for assistance in the field. We thank Maxime Réjou-Méchain for helpful discussions. This work has benefitted from “Investissement d'Avenir" grants managed by Agence Nationale de la Recherche (CEBA, ANR-10-LABX-25-01; ANAEE-France: ANR-11-INBS-0001).

\section{Authors'contributions}

I.M. planned and designed the research with contribution from M.K.B., L.S., and J.C.. I.M., M.K.B., and J.C collected the data. L.S.-A. contributed to chemical analysis. I.M. analyzed the data and wrote the manuscript with contributions from all authors. All authors gave final approval for publication.

\section{Data accessibility}


Data available from the Dryad Digital Repository: https://doi.org/10.5061/dryad.qnk98sfbq

(Maréchaux, Saint-André, Bartlett, Sack, \& Chave, 2019).

\section{References}

Allen, C. D., Macalady, A. K., Chenchouni, H., Bachelet, D., McDowell, N., Vennetier, M., ... Cobb, N. (2010). A global overview of drought and heat-induced tree mortality reveals emerging climate change risks for forests. Forest Ecology and Management, 259(4), 660684. doi: 10.1016/j.foreco.2009.09.001

Anderegg, L. D. L., Berner, L. T., Badgley, G., Sethi, M. L., Law, B. E., \& HilleRisLambers, J. (2018). Within-species patterns challenge our understanding of the leaf economics spectrum. Ecology Letters, 21(734-744). doi: 10.1111/ele.12945

Anderegg, W. R. L., Schwalm, C., Biondi, F., Camarero, J. J., Koch, G., Litvak, M., .. Pacala, S. (2015). Pervasive drought legacies in forest ecosystems and their implications for carbon cycle models. Science, 349(6247), 528-532. doi: 10.1126/science.aab1833

Anderson, D. L., Koomjian, W., French, B., Altenhoff, S. R., \& Luce, J. (2015). Review of ropebased access methods for the forest canopy: safe and unsafe practices in published information sources and a summary of current methods. Methods in Ecology and Evolution, 6(8), 865-872. doi: 10.1111/2041-210X.12393

Asner, G. P., Knapp, D. E., Anderson, C. B., Martin, R. E., \& Vaughn, N. (2016). Large-scale climatic and geophysical controls on the leaf economics spectrum. Proceedings of the National Academy of Sciences, 113(28), E4043-E4051. doi: 10.1073/pnas.1604863113

Asner, G. P., Martin, R. E., Tupayachi, R., Anderson, C. B., Sinca, F., Carranza-Jiménez, L., \& Martinez, P. (2014). Amazonian functional diversity from forest canopy chemical assembly. Proceedings of the National Academy of Sciences, 111(15), 5604-5609. doi: 10.1073/pnas.1401181111

Baltzer, J. L., \& Thomas, S. C. (2010). A Second Dimension to the Leaf Economics Spectrum Predicts Edaphic Habitat Association in a Tropical Forest. PLoS ONE, 5(10), e13163. doi: 10.1371/journal.pone.0013163

Baraloto, C., Timothy Paine, C. E., Poorter, L., Beauchene, J., Bonal, D., Domenach, A.-M., ... Chave, J. (2010). Decoupled leaf and stem economics in rain forest trees. Ecology Letters, 13(11), 1338-1347. doi: 10.1111/j.1461-0248.2010.01517.x

Bartlett, M. K., Zhang, Y., Yang, J., Kreidler, N., Sun, S.-W., Lin, L., ... Sack, L. (2016). Drought 
tolerance as a driver of tropical forest assembly: resolving spatial signatures for multiple processes. Ecology, 97(2), 503-514. doi: 10.1890/15-0468.1

Bartlett, Megan K., Klein, T., Jansen, S., Choat, B., \& Sack, L. (2016). The correlations and sequence of plant stomatal, hydraulic, and wilting responses to drought. Proceedings of the National Academy of Sciences, 113(46), 13098-13103. doi: 10.1073/pnas. 1604088113

Bartlett, Megan K., Scoffoni, C., Ardy, R., Zhang, Y., Sun, S., Cao, K., \& Sack, L. (2012). Rapid determination of comparative drought tolerance traits: using an osmometer to predict turgor loss point. Methods in Ecology and Evolution, 3(5), 880-888. doi: 10.1111/j.2041210X.2012.00230.X

Bartlett, Megan K., Scoffoni, C., \& Sack, L. (2012). The determinants of leaf turgor loss point and prediction of drought tolerance of species and biomes: a global meta-analysis. Ecology Letters, 15(5), 393-405. doi: 10.1111/j.1461-0248.2012.01751.x

Bartoń, K. (2015). MuMIn: Multi-Model Inference (Version R package version 1.13.4). Retrieved from http://CRAN.R-project.org/package=MuMIn

Baskerville, G. L. (1972). Use of Logarithmic Regression in the Estimation of Plant Biomass. Canadian Journal of Forest Research, 2(1), 49-53. doi: 10.1139/x72-009

Blackman, C. J. (2018). Leaf turgor loss as a predictor of plant drought response strategies. Tree Physiology, 38(5), 655-657. doi: 10.1093/treephys/tpy047

Blackman, C. J., Aspinwall, M. J., Resco de Dios, V., Smith, R. A., \& Tissue, D. T. (2016). Leaf photosynthetic, economics and hydraulic traits are decoupled among genotypes of a widespread species of eucalypt grown under ambient and elevated CO2. Functional Ecology, 30(9), 1491-1500. doi: 10.1111/1365-2435.12661

Brodribb, T. J. (2017). Progressing from 'functional' to mechanistic traits. New Phytologist, 215(1), 9-11. doi: 10.1111/nph.14620

Burnham, K. P., \& Anderson, D. R. (2003). Model Selection and Multimodel Inference: A Practical Information-Theoretic Approach. Springer Science \& Business Media.

Cardinale, B. J., Srivastava, D. S., Duffy, J. E., Wright, J. P., Downing, A. L., Sankaran, M., ... Michener, W. K. (2009). Effects of biodiversity on the functioning of ecosystems: a summary of 164 experimental manipulations of species richness. Ecology, 90(3), 854-854. doi: $10.1890 / 08-1584.1$

Cernusak, L. A., Ubierna, N., Winter, K., Holtum, J. A. M., Marshall, J. D., \& Farquhar, G. D. (2013). Environmental and physiological determinants of carbon isotope discrimination in 
terrestrial plants. New Phytologist, 200(4), 950-965. doi: 10.1111/nph.12423

Chave, J., Coomes, D., Jansen, S., Lewis, S. L., Swenson, N. G., \& Zanne, A. E. (2009). Towards a worldwide wood economics spectrum. Ecology Letters, 12(4), 351-366. doi: 10.1111/j.1461-0248.2009.01285.x

Choat, B., Jansen, S., Brodribb, T. J., Cochard, H., Delzon, S., Bhaskar, R., ... Zanne, A. E. (2012). Global convergence in the vulnerability of forests to drought. Nature, 491(7426), 752-755. doi: 10.1038/nature11688

Christoffersen, B. O., Gloor, M., Fauset, S., Fyllas, N. M., Galbraith, D. R., Baker, T. R., ... Meir, P. (2016). Linking hydraulic traits to tropical forest function in a size-structured and traitdriven model (TFS v.1-Hydro). Geoscientif Model Development, 9(11), 4227-4255. doi: 10.5194/gmd-9-4227-2016

Clark, J. S. (2010). Individuals and the Variation Needed for High Species Diversity in Forest Trees. Science, 327(5969), 1129-1132. doi: 10.1126/science.1183506

Clark, J. S., Bell, D. M., Hersh, M. H., Kwit, M. C., Moran, E., Salk, C., ... Zhu, K. (2011). Individual-scale variation, species-scale differences: inference needed to understand diversity. Ecology Letters, 14(12), 1273-1287. doi: 10.1111/j.1461-0248.2011.01685.x

Cochard, H., Badel, E., Herbette, S., Delzon, S., Choat, B., \& Jansen, S. (2013). Methods for measuring plant vulnerability to cavitation: a critical review. Journal of Experimental Botany, ert193. doi: 10.1093/jxb/ert193

Cornelissen, J. H. C., Lavorel, S., Garnier, E., Díaz, S., Buchmann, N., Gurvich, D. E., ... Poorter, H. (2003). A handbook of protocols for standardised and easy measurement of plant functional traits worldwide. Australian Journal of Botany, 51(4), 335-380.

De Guzman, M. E., Santiago, L. S., Schnitzer, S. A., \& Álvarez-Cansino, L. (2017). Trade-offs between water transport capacity and drought resistance in neotropical canopy liana and tree species. Tree Physiology, 37(10), 1404-1414. doi: 10.1093/treephys/tpw086

Demarty, M., Morvan, C., \& Thellier, M. (1984). Calcium and the cell wall. Plant, Cell \& Environment, 7(6), 441-448. doi: 10.1111/j.1365-3040.1984.tb01434.x

Díaz, S., Kattge, J., Cornelissen, J. H. C., Wright, I. J., Lavorel, S., Dray, S., ... Gorné, L. D. (2016). The global spectrum of plant form and function. Nature, 529(7585), 167-171. doi: 10.1038/nature16489

Domingues, Tomas F., Berry, J. A., Martinelli, L. A., Ometto, J. P. H. B., \& Ehleringer, J. R. (2005). Parameterization of Canopy Structure and Leaf-Level Gas Exchange for an Eastern 
Amazonian Tropical Rain Forest (Tapajós National Forest, Pará, Brazil). Earth Interactions, 9(17), 1-23. doi: 10.1175/EI149.1

Domingues, Tomas Ferreira, Meir, P., Feldpausch, T. R., Saiz, G., Veenendaal, E. M., Schrodt, F., ... Lloyd, J. (2010). Co-limitation of photosynthetic capacity by nitrogen and phosphorus in West Africa woodlands. Plant, Cell \& Environment, 33(6), 959-980. doi: 10.1111/j.13653040.2010.02119.x

Dray, S., \& Dufour, A.-B. (2007). The ade4 package: implementing the duality diagram for ecologists. Journal of Statistical Software, 22(4), 1-20.

Esperón-Rodríguez, M., Curran, T. J., Camac, J. S., Hofmann, R. W., Correa-Metrio, A., \& Barradas, V. L. (2018). Correlation of drought traits and the predictability of osmotic potential at full leaf turgor in vegetation from New Zealand. Austral Ecology, $0(0)$. doi: 10.1111/aec.12577

Evans, J. R. (1989). Photosynthesis and nitrogen relationships in leaves of $\mathrm{C}_{3}$ plants. Oecologia, 78(1), 9-19.

Farquhar, G. D., Caemmerer, S. von, \& Berry, J. A. (1980). A biochemical model of photosynthetic CO2 assimilation in leaves of C3 species. Planta, 149(1), 78-90.

Farquhar, G. D., Ehleringer, J. R., \& Hubick, K. T. (1989). Carbon Isotope Discrimination and Photosynthesis. Annual Review of Plant Physiology and Plant Molecular Biology, 40(1), 503-537. doi: 10.1146/annurev.pp.40.060189.002443

Farquhar, G., O’Leary, M., \& Berry, J. (1982). On the Relationship Between Carbon Isotope Discrimination and the Intercellular Carbon Dioxide Concentration in Leaves. Functional Plant Biology, 9(2), 121-137.

Fortunel, C., Fine, P. V. A., \& Baraloto, C. (2012). Leaf, stem and root tissue strategies across 758 Neotropical tree species. Functional Ecology, 26(5), 1153-1161. doi: 10.1111/j.13652435.2012.02020.x

Fox, J., \& Weisberg, S. (2011). An $\{R\}$ Companion to Applied Regression. Retrieved from http://socserv.socsci.mcmaster.ca/jfox/Books/Companion

Franks, P. J., Drake, P. L., \& Beerling, D. J. (2009). Plasticity in maximum stomatal conductance constrained by negative correlation between stomatal size and density: an analysis using Eucalyptus globulus. Plant, Cell \& Environment, 32(12), 1737-1748. doi: 10.1111/j.13653040.2009.002031.x

Funk, J. L., \& Cornwell, W. K. (2013). Leaf traits within communities: Context may affect the 
mapping of traits to function. Ecology, 94(9), 1893-1897. doi: 10.1890/12-1602.1

Fyllas, N. M., Patiño, S., Baker, T. R., Bielefeld Nardoto, G., Martinelli, L. A., Quesada, C. A., ... Lloyd, J. (2009). Basin-wide variations in foliar properties of Amazonian forest: phylogeny, soils and climate. Biogeosciences, 6(11), 2677-2708. doi: 10.5194/bg-6-2677-2009

Garten, C. T. (1976). Correlations between concentrations of elements in plants. Nature, 261(5562), 686-688. doi: 10.1038/261686a0

Gleason, S. M., Westoby, M., Jansen, S., Choat, B., Hacke, U. G., Pratt, R. B., ... Zanne, A. E. (2016). Weak tradeoff between xylem safety and xylem-specific hydraulic efficiency across the world's woody plant species. New Phytologist, 209(1), 123-136. doi: 10.1111/nph.13646

Griffin-Nolan, R. J., Bushey, J. A., Carroll, C. J. W., Challis, A., Chieppa, J., Garbowski, M., ... Knapp, A. K. (2018). Trait selection and community weighting are key to understanding ecosystem responses to changing precipitation regimes. Functional Ecology, 32(7), 17461756. doi: 10.1111/1365-2435.13135

Harrell, F. E., \& Dupont, C. (2015). Hmisc: harrell miscellaneous (Version R package version 3.15-0.). Retrieved from http://CRAN.R-project.org/package=Hmisc

Henry, C., John, G. P., Pan, R., Bartlett, M. K., Fletcher, L. R., Scoffoni, C., \& Sack, L. (2019). A stomatal safety-efficiency trade-off constrains responses to leaf dehydration. Nature Communications, 10(1), 1-9. doi: 10.1038/s41467-019-11006-1

Hochberg, U., Rockwell, F. E., Holbrook, N. M., \& Cochard, H. (2018). Iso/Anisohydry: A PlantEnvironment Interaction Rather Than a Simple Hydraulic Trait. Trends in Plant Science, 23(2), 112-120. doi: 10.1016/j.tplants.2017.11.002

Hodgson, J. G., Wilson, P. J., Hunt, R., Grime, J. P., \& Thompson, K. (1999). Allocating C-S-R plant functional types: a soft approach to a hard problem. Oikos, 85(2), 282-294. doi: $10.2307 / 3546494$

Hollingsworth, P. M., Graham, S. W., \& Little, D. P. (2011). Choosing and Using a Plant DNA Barcode. PLOS ONE, 6(5), e19254. doi: 10.1371/journal.pone.0019254

Jackson, D. A. (1993). Stopping Rules in Principal Components Analysis: A Comparison of Heuristical and Statistical Approaches. Ecology, 74(8), 2204-2214. doi: 10.2307/1939574

Kattge, J., Díaz, S., Lavorel, S., Prentice, I. C., Leadley, P., Bönisch, G., ... Wirth, C. (2011). TRY - a global database of plant traits. Global Change Biology, 17(9), 2905-2935. doi: 10.1111/j.1365-2486.2011.02451.x

Keenan, T. F., \& Niinemets, Ü. (2016). Global leaf trait estimates biased due to plasticity in the 
shade. Nature Plants, 3, 16201. doi: 10.1038/nplants.2016.201

Kutner, M. H., Nachtsheim, C. J., \& Neter, J. (2004). Applied linear regression models. (Fourth edition.). New York, NY, USA: McGraw-Hill.

Laughlin, D. C. (2014). The intrinsic dimensionality of plant traits and its relevance to community assembly. Journal of Ecology, 102(1), 186-193. doi: 10.1111/1365-2745.12187

Laughlin, D. C., Lusk, C. H., Bellingham, P. J., Burslem, D. F. R. P., Simpson, A. H., \& KramerWalter, K. R. (2017). Intraspecific trait variation can weaken interspecific trait correlations when assessing the whole-plant economic spectrum. Ecology and Evolution, 7(21), 89368949. doi: 10.1002/ece3.3447

Lavorel, S., Díaz, S., Cornelissen, J. H. C., Garnier, E., Harrison, S. P., McIntyre, S., ... Urcelay, C. (2007). Plant functional types: are we getting any closer to the Holy Grail? In J. G. Canadell, D. E. Pataki, \& L. F. Pitelka (Eds.), Terrestrial Ecosystems in a Changing World (pp. 149-164). Retrieved from http://link.springer.com/chapter/10.1007/978-3-540-327301

Leigh, R. A., \& Wyn Jones, R. G. (1984). A hypothesis relating critical potassium concentrations for growth to the distribution and functions of this ion in the plant cell. New Phytologist, 97(1), 1-13. doi: 10.1111/j.1469-8137.1984.tb04103.x

Li, L., McCormack, M. L., Ma, C., Kong, D., Zhang, Q., Chen, X., ... Guo, D. (2015). Leaf economics and hydraulic traits are decoupled in five species-rich tropical-subtropical forests. Ecology Letters, 18(9), 899-906. doi: 10.1111/ele.12466

Li, Ximeng, Blackman, C. J., Choat, B., Duursma, R. A., Rymer, P. D., Medlyn, B. E., \& Tissue, D. T. (2018). Tree hydraulic traits are coordinated and strongly linked to climate-of-origin across a rainfall gradient. Plant, Cell \& Environment, 41(3), 646-660. doi: 10.1111/pce.13129

Li, Xuefei, Pei, K., Kéry, M., Niklaus, P. A., \& Schmid, B. (2017). Decomposing functional trait associations in a Chinese subtropical forest. PLOS ONE, 12(4), e0175727. doi: 10.1371/journal.pone.0175727

MacArthur, R. H. (1972). Geographical Ecology: Patterns in the Distribution of Species. Princeton, NJ, USA: Princeton University Press.

Maréchaux, I., Bartlett, M. K., Gaucher, P., Sack, L., \& Chave, J. (2016). Causes of variation in leaf-level drought tolerance within an Amazonian forest. Journal of Plant Hydraulics, 3 , e004. 
Maréchaux, I., Bartlett, M. K., Sack, L., Baraloto, C., Engel, J., Joetzjer, E., \& Chave, J. (2015). Drought tolerance as predicted by leaf water potential at turgor loss point varies strongly across species within an Amazonian forest. Functional Ecology, 29(10), 1268-1277. doi: $10.1111 / 1365-2435.12452$

Maréchaux, I., Bonal, D., Bartlett, M. K., Burban, B., Coste, S., Courtois, E. A., ... Chave, J. (2018). Dry-season decline in tree sapflux is correlated with leaf turgor loss point in a tropical rainforest. Functional Ecology, 32(10), 2285-2297. doi: 10.1111/1365-2435.13188

Maréchaux, I., Saint-André, L., Bartlett, M. K., Sacl, L., \& Chave, J. (2019). Data from: Leaf drought tolerance cannot be inferred from classic leaf traits in a tropical rainforest. Dryad Digital Repository, https://doi.org/10.5061/dryad.qnk98sfbq

Martin-StPaul, N., Delzon, S., \& Cochard, H. (2017). Plant resistance to drought depends on timely stomatal closure. Ecology Letters, 20(11), 1437-1447. doi: 10.1111/ele.12851

Medeiros, C. D., Scoffoni, C., John, G. P., Bartlett, M. K., Inman-Narahari, F., Ostertag, R., ... Sack, L. (2019). An extensive suite of functional traits distinguishes Hawaiian wet and dry forests and enables prediction of species vital rates. Functional Ecology, 33(4), 712-734. doi: $10.1111 / 1365-2435.13229$

Medlyn, B. E., De Kauwe, M. G., \& Duursma, R. A. (2016). New developments in the effort to model ecosystems under water stress. New Phytologist, 212(1), 5-7. doi: 10.1111/nph.14082

Meinzer, F. C., Johnson, D. M., Lachenbruch, B., McCulloh, K. A., \& Woodruff, D. R. (2009). Xylem hydraulic safety margins in woody plants: coordination of stomatal control of xylem tension with hydraulic capacitance. Functional Ecology, 23(5), 922-930. doi: 10.1111/j.1365-2435.2009.01577.x

Meinzer, F. C., Smith, D. D., Woodruff, D. R., Marias, D. E., McCulloh, K. A., Howard, A. R., \& Magedman, A. L. (2017). Stomatal kinetics and photosynthetic gas exchange along a continuum of isohydric to anisohydric regulation of plant water status. Plant, Cell \& Environment, 40(8), 1618-1628. doi: 10.1111/pce.12970

Meinzer, F. C., Woodruff, D. R., Domec, J.-C., Goldstein, G., Campanello, P. I., Gatti, M. G., \& Villalobos-Vega, R. (2008). Coordination of leaf and stem water transport properties in tropical forest trees. Oecologia, 156(1), 31-41. doi: 10.1007/s00442-008-0974-5

Meinzer, F. C., Woodruff, D. R., Marias, D. E., Smith, D. D., McCulloh, K. A., Howard, A. R., \& Magedman, A. L. (2016). Mapping 'hydroscapes' along the iso- to anisohydric continuum of stomatal regulation of plant water status. Ecology Letters, 19(11), 1343-1352. doi:

This article is protected by copyright. All rights reserved 
10.1111/ele. 12670

Messier, J., McGill, B. J., Enquist, B. J., \& Lechowicz, M. J. (2017). Trait variation and integration across scales: is the leaf economic spectrum present at local scales? Ecography, 40(6), 685-697. doi: 10.1111/ecog.02006

Messier, J., McGill, B. J., \& Lechowicz, M. J. (2010). How do traits vary across ecological scales? A case for trait-based ecology. Ecology Letters, 13(7), 838-848. doi: 10.1111/j.14610248.2010.01476.x

Mokany, K., Ferrier, S., Connolly, S. R., Dunstan, P. K., Fulton, E. A., Harfoot, M. B., ... Wintle, B. A. (2016). Integrating modelling of biodiversity composition and ecosystem function. Oikos, 125(1), 10-19. doi: 10.1111/oik.02792

Niinemets, Ü., Keenan, T. F., \& Hallik, L. (2015). A worldwide analysis of within-canopy variations in leaf structural, chemical and physiological traits across plant functional types. New Phytologist, 205(3), 973-993. doi: 10.1111/nph.13096

Nolf, M., Creek, D., Duursma, R., Holtum, J., Mayr, S., \& Choat, B. (2015). Stem and leaf hydraulic properties are finely coordinated in three tropical rain forest tree species. Plant, Cell \& Environment, 38(12), 2652-2661. doi: 10.1111/pce.12581

O’Brien, M. J., Engelbrecht, B. M. J., Joswig, J., Pereyra, G., Schuldt, B., Jansen, S., ... Macinnis-Ng, C. (2017). A synthesis of tree functional traits related to drought-induced mortality in forests across climatic zones. Journal of Applied Ecology, 54(6), 1669-1686. doi: $10.1111 / 1365-2664.12874$

Olden, J. D., \& Jackson, D. A. (2000). Torturing data for the sake of generality: How valid are our regression models? Écoscience, 7(4), 501-510. doi: 10.1080/11956860.2000.11682622

Olivares, E., \& Medina, E. (1992). Water and nutrient relations of woody perennials from tropical dry forests. Journal of Vegetation Science, 3(3), 383-392. doi: 10.2307/3235764

Ometto, J. P. H. B., Ehleringer, J. R., Domingues, T. F., Berry, J. A., Ishida, F. Y., Mazzi, E., ... Martinelli, L. A. (2006). The stable carbon and nitrogen isotopic composition of vegetation in tropical forests of the Amazon Basin, Brazil. Biogeochemistry, 79(1-2), 251-274. doi: $10.1007 / \mathrm{s} 10533-006-9008-8$

Paine, C. E. T., Deasey, A., \& Duthie, A. B. (2018). Towards the general mechanistic prediction of community dynamics. Functional Ecology, 32(7), 1681-1692. doi: 10.1111/13652435.13096

Patiño, S., Fyllas, N. M., Baker, T. R., Paiva, R., Quesada, C. A., Santos, A. J. B., ... Lloyd, J. 
(2012). Coordination of physiological and structural traits in Amazon forest trees. Biogeosciences, 9(2), 775-801. doi: 10.5194/bg-9-775-2012

Peres-Neto, P. R., Jackson, D. A., \& Somers, K. M. (2003). Giving Meaningful Interpretation to Ordination Axes: Assessing Loading Significance in Principal Component Analysis. Ecology, 84(9), 2347-2363. doi: 10.1890/00-0634

Pérez-Harguindeguy, N., Díaz, S., Garnier, E., Lavorel, S., Poorter, H., Jaureguiberry, P., ... Cornelissen, J. H. C. (2013). New handbook for standardised measurement of plant functional traits worldwide. Australian Journal of Botany, 61(3), 167-234.

Piñeiro, G., Perelman, S., Guerschman, J. P., \& Paruelo, J. M. (2008). How to evaluate models: Observed vs. predicted or predicted vs. observed? Ecological Modelling, 216(3), 316-322. doi: 10.1016/j.ecolmodel.2008.05.006

Poorter, H., Niinemets, Ü., Poorter, L., Wright, I. J., \& Villar, R. (2009). Causes and consequences of variation in leaf mass per area (LMA): a meta-analysis. New Phytologist, 182(3), 565588. doi: 10.1111/j.1469-8137.2009.02830.x

Poorter, L., Castilho, C. V., Schietti, J., Oliveira, R. S., \& Costa, F. R. C. (2018). Can traits predict individual growth performance? A test in a hyperdiverse tropical forest. New Phytologist, 219(1), 109-121. doi: 10.1111/nph.15206

Powell, T. L., Wheeler, J. K., de Oliveira, A. A. R., da Costa, A. C. L., Saleska, S. R., Meir, P., \& Moorcroft, P. R. (2017). Differences in xylem and leaf hydraulic traits explain differences in drought tolerance among mature Amazon rainforest trees. Global Change Biology, 23(10), 4280-4293. doi: $10.1111 /$ gcb.13731

Prentice, I. C., Bondeau, A., Cramer, W., Harrison, S. P., Hickler, T., Lucht, W., ... Sykes, M. T. (2007). Dynamic Global Vegetation Modeling: Quantifying Terrestrial Ecosystem Responses to Large-Scale Environmental Change. In J. G. Canadell, D. E. Pataki, \& L. F. Pitelka (Eds.), Terrestrial ecosystems in a changing world (pp. 175-192). Retrieved from http://link.springer.com/chapter/10.1007/978-3-540-32730-1_15

R Core Team. (2018). R: a language and environment for statistical computing. Retrieved from http://www.R-project.org/

Ray-Mukherjee, J., Nimon, K., Mukherjee, S., Morris, D. W., Slotow, R., \& Hamer, M. (2014). Using commonality analysis in multiple regressions: a tool to decompose regression effects in the face of multicollinearity. Methods in Ecology and Evolution, 5(4), 320-328. doi: 10.1111/2041-210X.12166

This article is protected by copyright. All rights reserved 
Reich, P. B. (2014). The world-wide 'fast-slow' plant economics spectrum: a traits manifesto. Journal of Ecology, 102(2), 275-301. doi: 10.1111/1365-2745.12211

Reich, P. B., Oleksyn, J., \& Wright, I. J. (2009). Leaf phosphorus influences the photosynthesisnitrogen relation: a cross-biome analysis of 314 species. Oecologia, 160(2), 207-212. doi: $10.1007 / \mathrm{s} 00442-009-1291-3$

Reich, P. B., Walters, M. B., \& Ellsworth, D. S. (1997). From tropics to tundra: global convergence in plant functioning. Proceedings of the National Academy of Sciences, 94(25), $13730-13734$.

Roelfsema, M. R. G., \& Hedrich, R. (2005). In the light of stomatal opening: new insights into 'the Watergate.' New Phytologist, 167(3), 665-691. doi: 10.1111/j.1469-8137.2005.01460.x

Rosas, T., Mencuccini, M., Barba, J., Cochard, H., Saura-Mas, S., \& Martínez-Vilalta, J. (2019). Adjustments and coordination of hydraulic, leaf and stem traits along a water availability gradient. New Phytologist, 223(2), 632-646. doi: 10.1111/nph.15684

Roumet, C., Birouste, M., Picon-Cochard, C., Ghestem, M., Osman, N., Vrignon-Brenas, S., ... Stokes, A. (2016). Root structure-function relationships in 74 species: evidence of a root economics spectrum related to carbon economy. New Phytologist, 210(3), 815-826. doi: $10.1111 / \mathrm{nph} .13828$

Sack, L., Scoffoni, C., John, G. P., Poorter, H., Mason, C. M., Mendez-Alonzo, R., \& Donovan, L. A. (2013). How do leaf veins influence the worldwide leaf economic spectrum? Review and synthesis. Journal of Experimental Botany, 64(13), 4053-4080. doi: 10.1093/jxb/ert316

Sack, L., Scoffoni, C., John, G. P., Poorter, H., Mason, C. M., Mendez-Alonzo, R., \& Donovan, L. A. (2014). Leaf mass per area is independent of vein length per area: avoiding pitfalls when modelling phenotypic integration (reply to ). Journal of Experimental Botany, 65(18), 51155123. doi: 10.1093/jxb/eru305

Sack, L., Scoffoni, C., McKown, A. D., Frole, K., Rawls, M., Havran, J. C., ... Tran, T. (2012). Developmentally based scaling of leaf venation architecture explains global ecological patterns. Nature Communications, 3, 837. doi: 10.1038/ncomms 1835

Sakschewski, B., von Bloh, W., Boit, A., Rammig, A., Kattge, J., Poorter, L., ... Thonicke, K. (2015). Leaf and stem economics spectra drive diversity of functional plant traits in a dynamic global vegetation model. Global Change Biology, 21(7), 2711-2725. doi: $10.1111 /$ gcb. 12870

Santiago, L. S., Goldstein, G., Meinzer, F. C., Fisher, J. B., Machado, K., Woodruff, D., \& Jones, 
T. (2004). Leaf photosynthetic traits scale with hydraulic conductivity and wood density in Panamanian forest canopy trees. Oecologia, 140(4), 543-550. doi: 10.1007/s00442-0041624-1

Santiago, L. S., \& Wright, S. J. (2007). Leaf functional traits of tropical forest plants in relation to growth form. Functional Ecology, 21(1), 19-27. doi: 10.1111/j.1365-2435.2006.01218.x

Scheiter, S., Langan, L., \& Higgins, S. I. (2013). Next-generation dynamic global vegetation models: learning from community ecology. New Phytologist, 198(3), 957-969. doi: 10.1111/nph.12210

Scoffoni, C., Rawls, M., McKown, A., Cochard, H., \& Sack, L. (2011). Decline of leaf hydraulic conductance with dehydration: relationship to leaf size and venation architecture. Plant Physiology, 156(2), 832-843. doi: 10.1104/pp.111.173856

Siefert, A., Violle, C., Chalmandrier, L., Albert, C. H., Taudiere, A., Fajardo, A., ... Chase, J. (2015). A global meta-analysis of the relative extent of intraspecific trait variation in plant communities. Ecology Letters, 18(12), 1406-1419. doi: 10.1111/ele.12508

Van Bodegom, P. M., Douma, J. C., Witte, J. P. M., Ordoñez, J. C., Bartholomeus, R. P., \& Aerts, R. (2012). Going beyond limitations of plant functional types when predicting global ecosystem-atmosphere fluxes: exploring the merits of traits-based approaches. Global Ecology and Biogeography, 21(6), 625-636. doi: 10.1111/j.1466-8238.2011.00717.x

Violle, C., Navas, M.-L., Vile, D., Kazakou, E., Fortunel, C., Hummel, I., \& Garnier, E. (2007). Let the concept of trait be functional! Oikos, 116(5), 882-892. doi: 10.1111/j.00301299.2007.15559.x

Warton, D. I., Duursma, R. A., Falster, D. S., \& Taskinen, S. (2012). smatr 3- an R package for estimation and inference about allometric lines. Methods in Ecology and Evolution, 3(2), 257-259. doi: 10.1111/j.2041-210X.2011.00153.x

Wenger, S. J., \& Olden, J. D. (2012). Assessing transferability of ecological models: an underappreciated aspect of statistical validation. Methods in Ecology and Evolution, 3(2), 260-267. doi: 10.1111/j.2041-210X.2011.00170.x

Westoby, M., \& Wright, I. J. (2006). Land-plant ecology on the basis of functional traits. Trends in Ecology \& Evolution, 21(5), 261-268. doi: 10.1016/j.tree.2006.02.004

Wright, I. J., Dong, N., Maire, V., Prentice, I. C., Westoby, M., Díaz, S., .. Wilf, P. (2017). Global climatic drivers of leaf size. Science, 357(6354), 917-921. doi: $10.1126 /$ science.aal4760 
Wright, I. J., Falster, D. S., Pickup, M., \& Westoby, M. (2006). Cross-species patterns in the coordination between leaf and stem traits, and their implications for plant hydraulics. Physiologia Plantarum, 127(3), 445-456. doi: 10.1111/j.1399-3054.2006.00699.x

Wright, I. J., Reich, P. B., Cornelissen, J. H. C., Falster, D. S., Groom, P. K., Hikosaka, K., ... Westoby, M. (2005). Modulation of leaf economic traits and trait relationships by climate. Global Ecology and Biogeography, 14(5), 411-421. doi: 10.1111/j.1466-822x.2005.00172.x

Wright, I. J., Reich, P. B., Westoby, M., Ackerly, D. D., Baruch, Z., Bongers, F., ... Villar, R. (2004). The worldwide leaf economics spectrum. Nature, 428(6985), 821-827. doi: $10.1038 /$ nature 02403

Wright, I. J., \& Westoby, M. (2002). Leaves at low versus high rainfall: coordination of structure, lifespan and physiology. New Phytologist, 155(3), 403-416. doi: 10.1046/j.14698137.2002.00479.x

Xu, X., Medvigy, D., Powers, J. S., Becknell, J. M., \& Guan, K. (2016). Diversity in plant hydraulic traits explains seasonal and inter-annual variations of vegetation dynamics in seasonally dry tropical forests. New Phytologist, 212(1), 80-95. doi: 10.1111/nph.14009

Yang, J., Cao, M., \& Swenson, N. G. (2018). Why functional traits do not predict tree demographic rates. Trends in Ecology \& Evolution, 33(5), 326-336. doi: 10.1016/j.tree.2018.03.003

Zhu, S.-D., Chen, Y.-J., Ye, Q., He, P.-C., Liu, H., Li, R.-H., .. Cao, K.-F. (2018). Leaf turgor loss point is correlated with drought tolerance and leaf carbon economics traits. Tree Physiology, 38(5), 658-663. doi: 10.1093/treephys/tpy013

\section{Supporting information}

Additional supporting information could be found online in the Supporting Information section at the end of the article. 


\section{Tables}

Table 1. Study traits and their functional significance. For each trait is provided the symbol, units, mean, maximum and minimum as well as the coefficient of variation (CV) across the dataset ( $\mathrm{n}=134$ individuals). The different hypotheses regarding each trait relationship with $\pi_{\mathrm{tlp}}$, as well as their physiological or ecological underpinnings is provided: (+), (-) and (ns) denote a hypothesized positive, negative or an absence of relationship, respectively, with in bold the one supported by our results.

\begin{tabular}{|c|c|c|c|c|c|c|}
\hline Trait & $\begin{array}{l}\text { Abbre- } \\
\text { viation }\end{array}$ & Units & $\begin{array}{l}\text { Mean } \\
(\min , \\
\max )\end{array}$ & $\begin{array}{l}\mathrm{CV} \\
(\%)\end{array}$ & Functional significance & Hypothesized relationships with $\pi_{\mathrm{tlp}}$ \\
\hline $\begin{array}{l}\text { Leaf mass } \\
\text { per area }\end{array}$ & LMA & $\mathrm{g} \mathrm{m}^{-2}$ & $\begin{array}{c}84.15 \\
(27.80 \\
397.94)\end{array}$ & 56.0 & $\begin{array}{l}\text { Invested biomass per leaf area deployed; } \\
\text { depicts a trade-off between light interception } \\
\text { efficiency and leaf persistence (Poorter, } \\
\text { Niinemets, Poorter, Wright, \& Villar, 2009) }\end{array}$ & $\begin{array}{l}\text { (-) 'fast-slow' hypothesis }{ }^{1} \text { (Medeiros et al., } \\
\text { 2019; Zhu et al., 2018) } \\
\text { (ns) absence of mechanistic link (Bartlett, } \\
\text { Scoffoni, \& Sack, 2012; Maréchaux et al., 2015) }\end{array}$ \\
\hline Leaf area & LA & $\mathrm{cm}^{2}$ & $\begin{array}{c}333.94 \\
(10.72 \\
5213.18)\end{array}$ & 257.1 & $\begin{array}{l}\text { Driver of light capture efficiency and leaf } \\
\text { boundary layer, which is thinner for smaller } \\
\text { leaves, facilitating sensible heat exchange } \\
\text { with the surrounding air and leaf cooling } \\
\text { (Wright et al., 2017) }\end{array}$ & $\begin{array}{c}(+) \text { 'fast-slow' hypothesis (Medeiros et al., 2019) } \\
(\mathrm{ns}) \text { absence of mechanistic link }\end{array}$ \\
\hline $\begin{array}{l}\text { Nitrogen } \\
\text { concentration }\end{array}$ & $\mathrm{N}_{\text {mass }}$ & $\mathrm{mg} \mathrm{g}^{-1}$ & $\begin{array}{l}20.26 \\
(7.50\end{array}$ & 28.7 & $\begin{array}{l}\text { N-rich compounds are essential to } \\
\text { photosynthesis and metabolic processes }\end{array}$ & $\begin{array}{l}\quad(+) \text { 'fast-slow' hypothesis } \\
(-) \text { drought resistant strategies combine higher }\end{array}$ \\
\hline
\end{tabular}

This article is protected by copyright. All rights reserved 


\begin{tabular}{|c|c|c|c|c|c|}
\hline per leaf mass & & & $39.30)$ & & (Evans, 1989). \\
\hline $\begin{array}{l}\text { Nitrogen } \\
\text { concentration } \\
\text { per leaf area }\end{array}$ & $\mathrm{N}_{\text {area }}$ & $\mathrm{g} \mathrm{m}^{-2}$ & $\begin{array}{r}1.58 \\
(0.59 \\
5.97)\end{array}$ & 45.6 & “ \\
\hline $\begin{array}{l}\text { Phosphorus } \\
\text { concentration } \\
\text { per leaf mass }\end{array}$ & $P_{\text {mass }}$ & $\mathrm{mg} \mathrm{g}^{-1}$ & $\begin{array}{l}0.77 \\
(0.30 \\
2.03)\end{array}$ & 41.0 & $\begin{array}{l}\text { P-rich compounds are essential to } \\
\text { photosynthesis and metabolic processes } \\
\text { (Reich, Oleksyn, \& Wright, 2009). }\end{array}$ \\
\hline $\begin{array}{l}\text { Phosphorus } \\
\text { concentration } \\
\text { per leaf area }\end{array}$ & $\mathrm{P}_{\text {area }}$ & $\mathrm{g} \mathrm{m}^{-2}$ & $\begin{array}{l}0.06 \\
(0.02 \\
0.34)\end{array}$ & 59.6 & “ \\
\hline $\begin{array}{l}\text { Potassium } \\
\text { concentration } \\
\text { per leaf mass }\end{array}$ & $\mathrm{K}_{\text {mass }}$ & $\mathrm{mg} \mathrm{g}^{-1}$ & $\begin{array}{l}7.28 \\
(2.45 \\
17.93)\end{array}$ & 48.0 & $\begin{array}{l}\text { Enzyme activator in metabolic reactions, has } \\
\text { an important role in stomatal movement, and } \\
\text { contribute to osmoregulation (Leigh \& Wyn } \\
\text { Jones, 1984; Roelfsema \& Hedrich, 2005). }\end{array}$ \\
\hline
\end{tabular}

leaf drought tolerance (more negative $\pi_{\text {tlp }}$ ) and higher nutrient concentration to enhance water conservation during photosynthesis (Meinzer et al., 2017; Wright \& Westoby, 2002)

(ns) absence of mechanistic link

(+) 'fast-slow' hypothesis (Baraloto et al., 2010)

(-) higher cation concentration values contribute to lowering leaf osmotic potentials resulting in more negative $\pi_{\mathrm{tlp}}$ (Olivares \& Medina, 1992; 


\begin{tabular}{|c|c|c|c|c|c|}
\hline $\begin{array}{l}\text { Potassium } \\
\text { concentration } \\
\text { per leaf area }\end{array}$ & $\mathrm{K}_{\mathrm{area}}$ & $\mathrm{g} \mathrm{m}^{-2}$ & $\begin{array}{c}0.60 \\
(0.11 \\
7.04)\end{array}$ & 109.2 & ، \\
\hline $\begin{array}{l}\text { Calcium } \\
\text { concentration } \\
\text { per leaf mass }\end{array}$ & $\mathrm{Ca}_{\text {mass }}$ & $\mathrm{mg} \mathrm{g}^{-1}$ & $\begin{array}{c}8.29 \\
(0.99 \\
37.54)\end{array}$ & 75.9 & $\begin{array}{c}\text { Enzyme activator in metabolic reactions, has } \\
\text { an important role in stomatal movement and } \\
\text { cell wall development (Demarty, Morvan, \& } \\
\text { Thellier, 1984; Roelfsema \& Hedrich, } \\
\text { 2005). }\end{array}$ \\
\hline $\begin{array}{l}\text { Calcium } \\
\text { concentration } \\
\text { per leaf area }\end{array}$ & $\mathrm{Ca}_{\text {area }}$ & $\mathrm{g} \mathrm{m}^{-2}$ & $\begin{array}{l}0.68 \\
(0.05 \\
3.56)\end{array}$ & 96.6 & "6 \\
\hline $\begin{array}{l}\text { Magnesium } \\
\text { concentration } \\
\text { per leaf mass }\end{array}$ & $\mathrm{Mg}_{\text {mass }}$ & $\mathrm{mg} \mathrm{g}^{-1}$ & $\begin{array}{l}2.65 \\
(0.35 \\
15.41)\end{array}$ & 78.1 & $\begin{array}{l}\text { Enzyme activator in metabolic reactions, has } \\
\text { an important role in chrophyll and lipid } \\
\text { production, and contribute to } \\
\text { osmoregulation (Garten, 1976; Leigh \& } \\
\text { Wyn Jones, 1984). }\end{array}$ \\
\hline
\end{tabular}

Patiño et al., 2012)

(ns) absence of mechanistic link

This article is protected by copyright. All rights reserved 


\begin{tabular}{|c|c|c|c|c|c|}
\hline $\begin{array}{l}\text { Magnesium } \\
\text { concentration } \\
\text { per leaf area }\end{array}$ & $\mathrm{Mg}_{\text {area }}$ & $\mathrm{g} \mathrm{m}^{-2}$ & $\begin{array}{l}0.22 \\
(0.03 \\
1.16)\end{array}$ & 93.2 & ، \\
\hline $\begin{array}{l}\text { Carbon } \\
\text { isotope ratio }\end{array}$ & $\delta^{13} \mathrm{C}$ & $\%$ & $\begin{array}{l}-33.16(- \\
37.87,- \\
27.92)\end{array}$ & 6.5 & $\begin{array}{l}\text { Informs pattern of carbon use, varies with C } \\
\text { source and fractionation during assimilation; } \\
\text { is positiviely related to water use efficiency } \\
\text { (Farquhar et al., 1989). }\end{array}$ \\
\hline $\begin{array}{l}\text { Carbon } \\
\text { concentration } \\
\text { per leaf mass }\end{array}$ & $\mathrm{C}_{\text {mass }}$ & $\%$ & $\begin{array}{l}45.59 \\
(40.46 \\
50.22)\end{array}$ & 4.8 & $\begin{array}{c}\text { Key component of leaf structural (e.g. } \\
\text { lignin) and non-structutral (e.g. proteins) } \\
\text { compounds }\end{array}$ \\
\hline $\begin{array}{l}\text { Time- } \\
\text { integrated } \\
\mathrm{CO}_{2} \\
\text { assimilation } \\
\text { rate per mass }\end{array}$ & $\overline{A_{\text {mass }}}$ & $\begin{array}{c}\mu \mathrm{mol} \mathrm{g} \mathrm{g}^{-1} \\
\mathrm{~s}^{-1}\end{array}$ & $\begin{array}{l}0.10 \\
(0.06 \\
0.14)\end{array}$ & 15.8 & (Farquhar et al., 1980; Franks et al., 2009) \\
\hline
\end{tabular}

(-) 'fast-slow' hypothesis (Medeiros et al., 2019; Rosas et al., 2019)

$(+)$ leaves with more negative $\pi_{\text {tlp }}$ have a more anisohydric behaviour and prioritize carbon gain over water use efficiency when soil water availability is not limited (Meinzer et al., 2017) (ns) absence of mechanistic link

(-) 'fast-slow' hypothesis (Medeiros et al., 2019) (ns) absence of mechanistic link

(+) 'fast-slow' hypothesis (Medeiros et al., 2019) (-) drought resistant strategies combine higher leaf drought tolerance (more negative $\pi_{\text {tlp }}$ ) and higher assimilation rate to enhance water conservation during photosynthesis (Meinzer et al., 2017; Wright \& Westoby, 2002) 


\begin{tabular}{|c|c|c|c|c|c|c|}
\hline & & & & & & (ns) absence of mechanistic link \\
\hline $\begin{array}{l}\text { Time- } \\
\text { integrated } \\
\mathrm{CO}_{2} \\
\text { assimilation } \\
\text { rate per area }\end{array}$ & $\overline{A_{\text {area }}}$ & $\begin{array}{c}\mu \mathrm{mol} \mathrm{m} \mathrm{m}^{-2} \\
\mathrm{~s}^{-1}\end{array}$ & $\begin{array}{l}8.23 \\
(2.29 \\
26.45)\end{array}$ & 46.0 & (Farquhar et al., 1980; Franks et al., 2009) & “ \\
\hline $\begin{array}{l}\text { Time- } \\
\text { integrated } \\
\text { stomatal } \\
\text { conductance } \\
\text { to water } \\
\text { vapour }\end{array}$ & $\overline{g_{w}}$ & $\begin{array}{c}\mathrm{mol} \mathrm{m}^{-2} \\
\mathrm{~s}^{-1}\end{array}$ & $\begin{array}{l}0.16 \\
(0.05 \\
0.71)\end{array}$ & 50.7 & (Farquhar et al., 1980; Franks et al., 2009) & $\begin{array}{l}(+) \text { 'fast-slow' hypothesis (Medeiros et al., } \\
\text { 2019), with less negative } \pi_{\mathrm{tlp}} \text { being related to } \\
\text { higher maximal } \mathrm{g}_{\mathrm{w}}(\text { Henry et al., 2019) and } \\
\text { higher } \mathrm{g}_{\mathrm{w}} \text { overall in a wet environment } \\
\text { (-) More negative } \pi_{\mathrm{tl}} \text { is related to increasing } \\
\text { anisohydry and greater leaf turgor, allowing } \\
\text { sustained greater } \mathrm{g}_{\mathrm{w}} \text { under drying conditions } \\
\text { (Maréchaux et al., 2018; Meinzer et al., 2016) } \\
\text { and overall (Meinzer et al., 2017) }\end{array}$ \\
\hline $\begin{array}{l}\text { Leaf water } \\
\text { potential at } \\
\text { turgor loss } \\
\text { point }\end{array}$ & $\pi_{\mathrm{tlp}}$ & $\mathrm{MPa}$ & $\begin{array}{c}-1.75(- \\
2.73,- \\
1.06)\end{array}$ & 19.9 & $\begin{array}{l}\text { Point at which leaf cells lose turgor and the } \\
\text { leaf wilts; more negative values indicate } \\
\text { more drought tolerant leaves (Bartlett, } \\
\text { Scoffoni, \& Sack, 2012). }\end{array}$ & - \\
\hline
\end{tabular}

This article is protected by copyright. All rights reserved 
${ }^{1}$ Hypothesis named upon Reich (2014) whereby biophysical constraints on plant structure and function impose coordinated trade-offs across traits at the whole plant scale and regarding all resources, resulting in species operating along a spectrum of 'fast' (acquisitive) to 'slow' (conservative)

strategies, with 'fast' strategies having traits that allow rapid acquisition of resources at the detriment of tissue persistence under various conditions and the opposite for 'slow' strategies.

This article is protected by copyright. All rights reserved 
Table 2. Pairwise correlations among the studied leaf traits. Pearson correlation coefficients are shown in bold type when significant, following Bonferroni-corrected alpha values $(\mathrm{P}<0.0003)$. Note that LMA, LA, $\mathrm{N}_{\text {area }}, \mathrm{P}_{\text {mass }}, \mathrm{P}_{\text {area }}, \mathrm{K}_{\text {mass }}, \mathrm{K}_{\text {area }}, \mathrm{Ca}_{\text {mass }}, \mathrm{Ca}_{\text {area }}, \mathrm{Mg}_{\text {mass }}, \mathrm{Mg}_{\text {area }}, \overline{g_{w}}$ and $\pi_{\mathrm{tlp}}$ were logtransformed to meet the assumption of normality. Since negative, $\pi_{\text {tlp }}$ values were converted to positive values for log transformation, but signs of correlation coefficients correspond to the correlation sign for untransformed data.

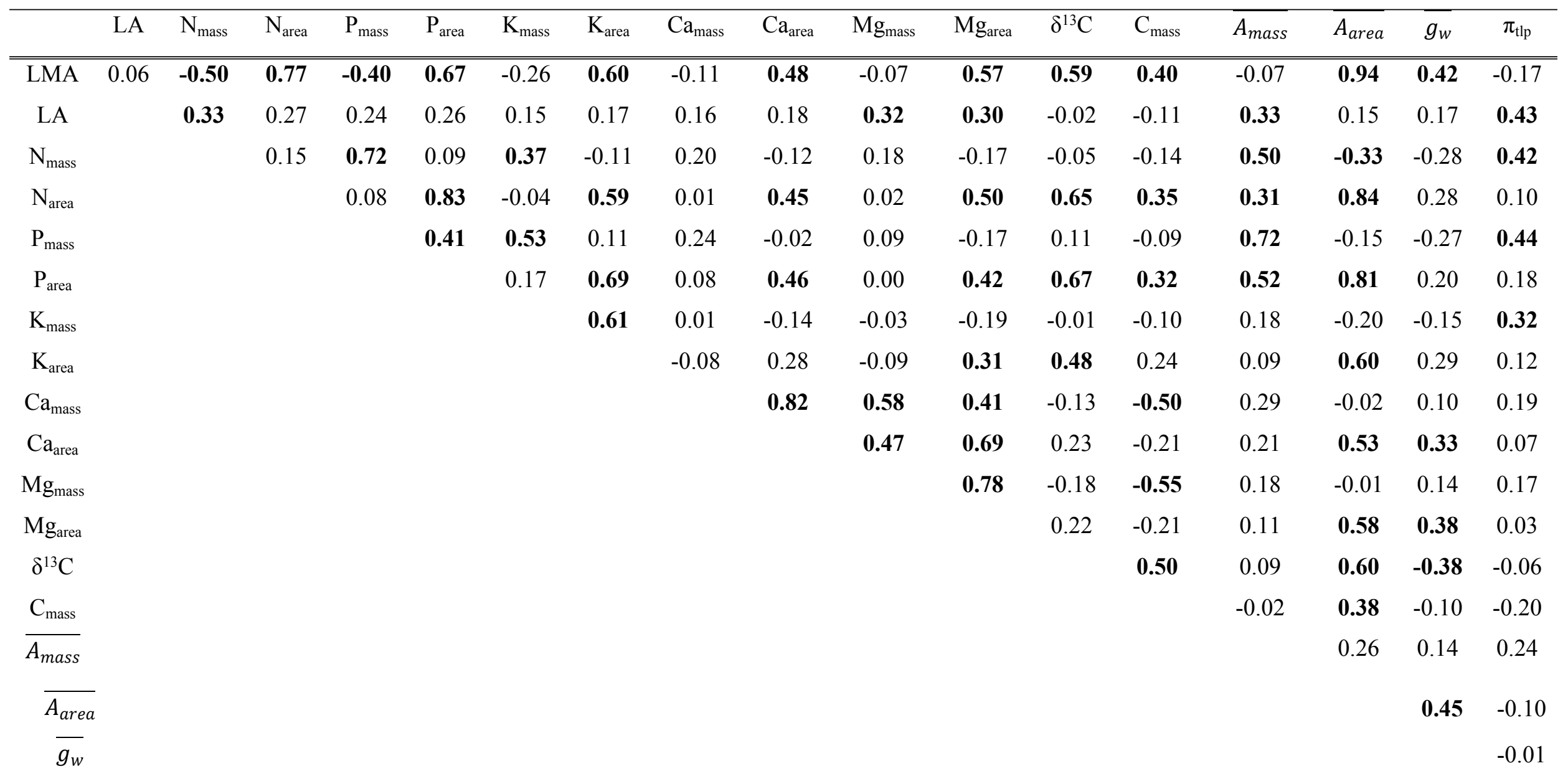


Table 3. Loading scores of 18 functional traits in the PCA on the whole dataset $(n=134$ individuals). Traits abbreviations are given in Table 1. Significant principal components (as determined by comparison with a broken stick model) and trait loadings with absolute values $>0.5$ are bolded. Since negative, $\pi_{\mathrm{tlp}}$ values were converted to positive values for log transformation, but signs of $\pi_{\text {tlp }}$ loadings correspond to the correlation sign for untransformed data.

\begin{tabular}{|c|c|c|c|c|c|}
\hline & PC1 & PC2 & PC3 & PC4 & PC5 \\
\hline Eigenvalue & 5.53 & 3.74 & 3.04 & 1.37 & 1.19 \\
\hline$\%$ of variance explained & 30.7 & 20.8 & 16.9 & 7.6 & 6.6 \\
\hline Cumulative variance & 30.7 & 51.5 & 68.4 & 76.0 & 82.6 \\
\hline \multicolumn{6}{|l|}{ Loadings of traits } \\
\hline LMA & -0.88 & 0.46 & -0.09 & -0.07 & 0.00 \\
\hline LA & -0.29 & -0.50 & -0.01 & -0.28 & 0.30 \\
\hline $\mathrm{N}_{\text {mass }}$ & 0.14 & -0.74 & 0.40 & 0.17 & 0.17 \\
\hline $\mathrm{N}_{\text {area }}$ & -0.89 & -0.01 & 0.20 & 0.07 & 0.14 \\
\hline$P_{\text {mass }}$ & -0.02 & -0.76 & $\mathbf{0 . 5 3}$ & 0.15 & 0.04 \\
\hline $\mathrm{P}_{\mathrm{area}}$ & -0.89 & -0.17 & 0.34 & 0.05 & 0.03 \\
\hline $\mathrm{K}_{\text {mass }}$ & 0.03 & -0.45 & 0.50 & -0.49 & -0.50 \\
\hline $\mathrm{K}_{\text {area }}$ & -0.70 & 0.00 & 0.34 & -0.46 & -0.42 \\
\hline $\mathrm{Ca}_{\text {mass }}$ & -0.17 & -0.61 & -0.53 & 0.27 & -0.21 \\
\hline $\mathrm{Ca}_{\text {area }}$ & -0.66 & -0.28 & -0.52 & 0.20 & -0.18 \\
\hline $\mathrm{Mg}_{\text {mass }}$ & -0.17 & -0.56 & -0.63 & 0.08 & -0.13 \\
\hline $\mathrm{Mg}_{\text {area }}$ & -0.69 & -0.18 & -0.58 & 0.03 & -0.11 \\
\hline$\delta^{13} \mathrm{C}$ & -0.63 & 0.21 & 0.44 & 0.45 & -0.28 \\
\hline $\mathrm{C}_{\text {mass }}$ & -0.29 & 0.52 & 0.55 & 0.15 & 0.21 \\
\hline$\overline{A_{\text {mass }}}$ & -0.32 & -0.62 & 0.26 & 0.17 & 0.43 \\
\hline$\overline{A_{\text {area }}}$ & -0.95 & 0.24 & -0.01 & 0.00 & 0.14 \\
\hline$\overline{g_{w}}$ & -0.39 & 0.05 & -0.44 & -0.58 & 0.44 \\
\hline$\pi_{\mathrm{tlp}}$ & -0.06 & -0.60 & 0.18 & -0.27 & 0.05 \\
\hline
\end{tabular}


Table 4. Performance of the model selected to predict the leaf water potential at turgor loss point based on the other studied leaf traits ${ }^{\mathrm{a}}$.

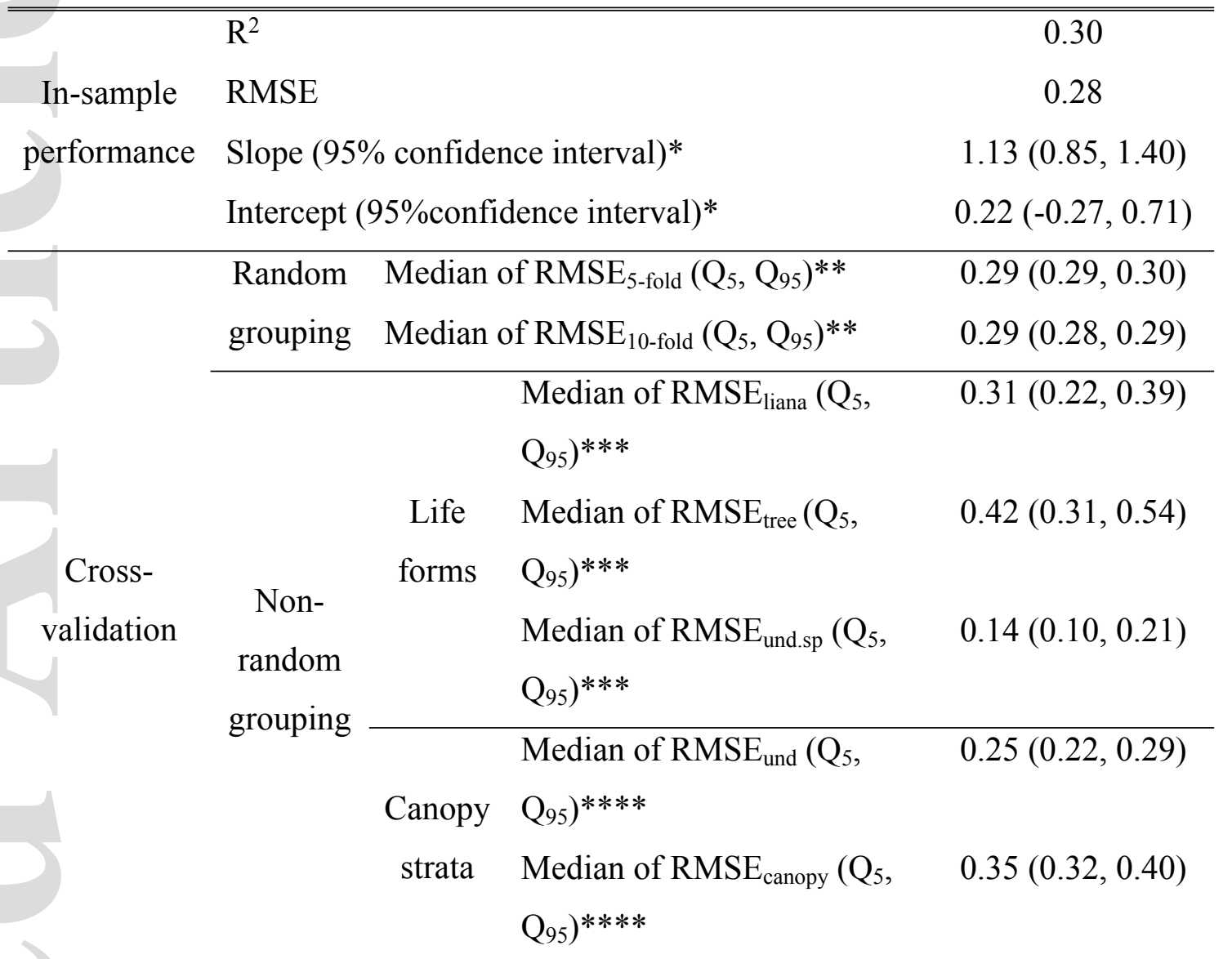

a Selected model: $\log \left(-\pi_{\text {tlp }}\right)=1.069-0.049 \times \log (\mathrm{LA})-0.008 \times \mathrm{N}_{\text {mass }}-0.072 \times \log \left(\mathrm{K}_{\text {mass }}\right)$ *Slope and intercept (and their 95\% confidence interval) of the linear regression between measured and predicted $\pi_{\mathrm{tlp}}$ values as shown in Fig. 2.

**Median, and $\mathrm{Q}_{5}$ and $\mathrm{Q}_{95}$ quantiles, of the distribution of $\mathrm{RMSE}_{5 \text {-fold }}$ and $\mathrm{RMSE}_{10 \text {-fold }}$ across 100 random partitions of the dataset into five and ten equal-sized groups respectively for crossvalidation. Histograms of the full distributions are provided in Fig.S6.

***Median, and $\mathrm{Q}_{5}$ and $\mathrm{Q}_{95}$ quantiles, of the distribution of $\mathrm{RMSE}_{\text {liana }}, \mathrm{RMSE}_{\text {tree, }}, \mathrm{RMSE}_{\text {und.sp }}$ across 100 random samplings of 15 among 70 trees, and 15 among 49 lianas. Such procedure aimed at performing cross-validation with three equal-sized groups, one for each life form, and hence being able to compare the RMSE distributions across life forms. Histograms of the full distributions are provided in Fig.S6.

*****Median, and $\mathrm{Q}_{5}$ and $\mathrm{Q}_{95}$ quantiles, of the distribution of $\mathrm{RMSE}_{\text {und }}$ and $\mathrm{RMSE}_{\text {canopy }}$ across 100 random samplings of 42 among 92 canopy individuals. Such procedure aimed at performing cross- 
validation with two equal-sized groups, one for each canopy strata, and hence being able to compare the RMSE distributions across canopy strata. Histograms of the full distributions are provided in Fig.S6.

This article is protected by copyright. All rights reserved 


\section{Figures}

Fig. 1. Pairwise relationships between leaf water potential at turgor loss point and eleven other leaf traits across 134 tropical plants in an Amazonian rainforest. See Table 1 for trait abbreviations and significance. Green dots: trees (including canopy trees and saplings); red dots: lianas (including canopy lianas and saplings); blue dots: understory species. Black lines are standardized major axis relationships that are significant across individuals and after Bonferroni correction $(\mathrm{P}<0.0003$; Table 2; Warton et al., 2012), dashed lines are relationships that are marginally significant across individuals $(0.0003<\mathrm{P}<0.5)$. In case of significantly different slopes across life forms, coloured lines represent significant relationships within life forms. See Fig. S4 with colours corresponding to canopy strata instead of life forms.

Fig. 2. Measured vs. predicted $\pi_{\mathrm{tlp}}$ values across the dataset ( $\mathrm{n}=134$ individuals) for the selected model. The black continuous line shows the fitted linear regression, and the dotted line shows the 1:1 line. See Table 4 for quantifications of the model performance. Green dots: trees (including canopy trees and saplings); red dots: lianas (including canopy lianas and saplings); blue dots: understory species. See Fig. S7 with colours corresponding to canopy strata instead of life forms. 
Fig. 1
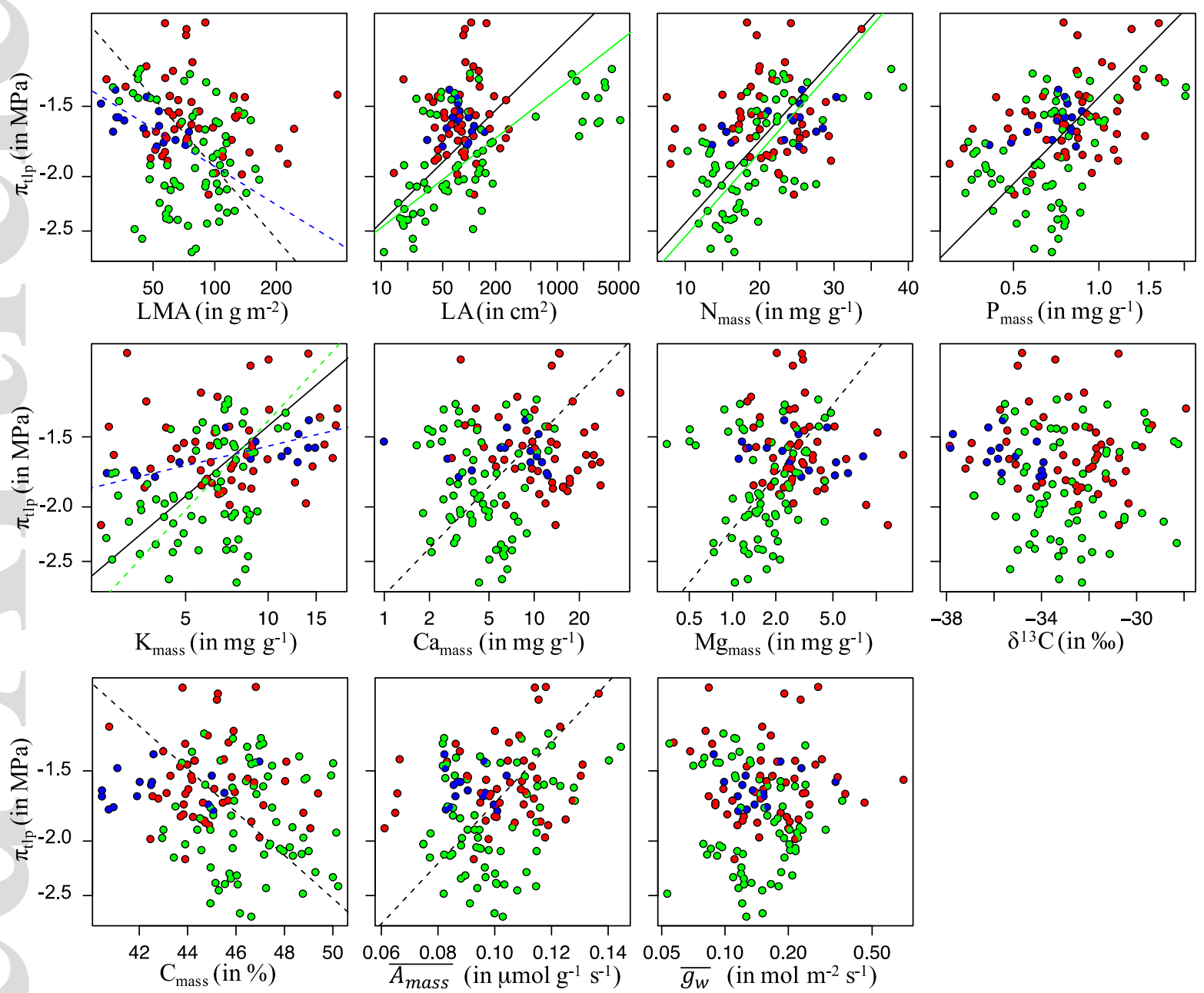

This article is protected by copyright. All rights reserved 
Fig. 2

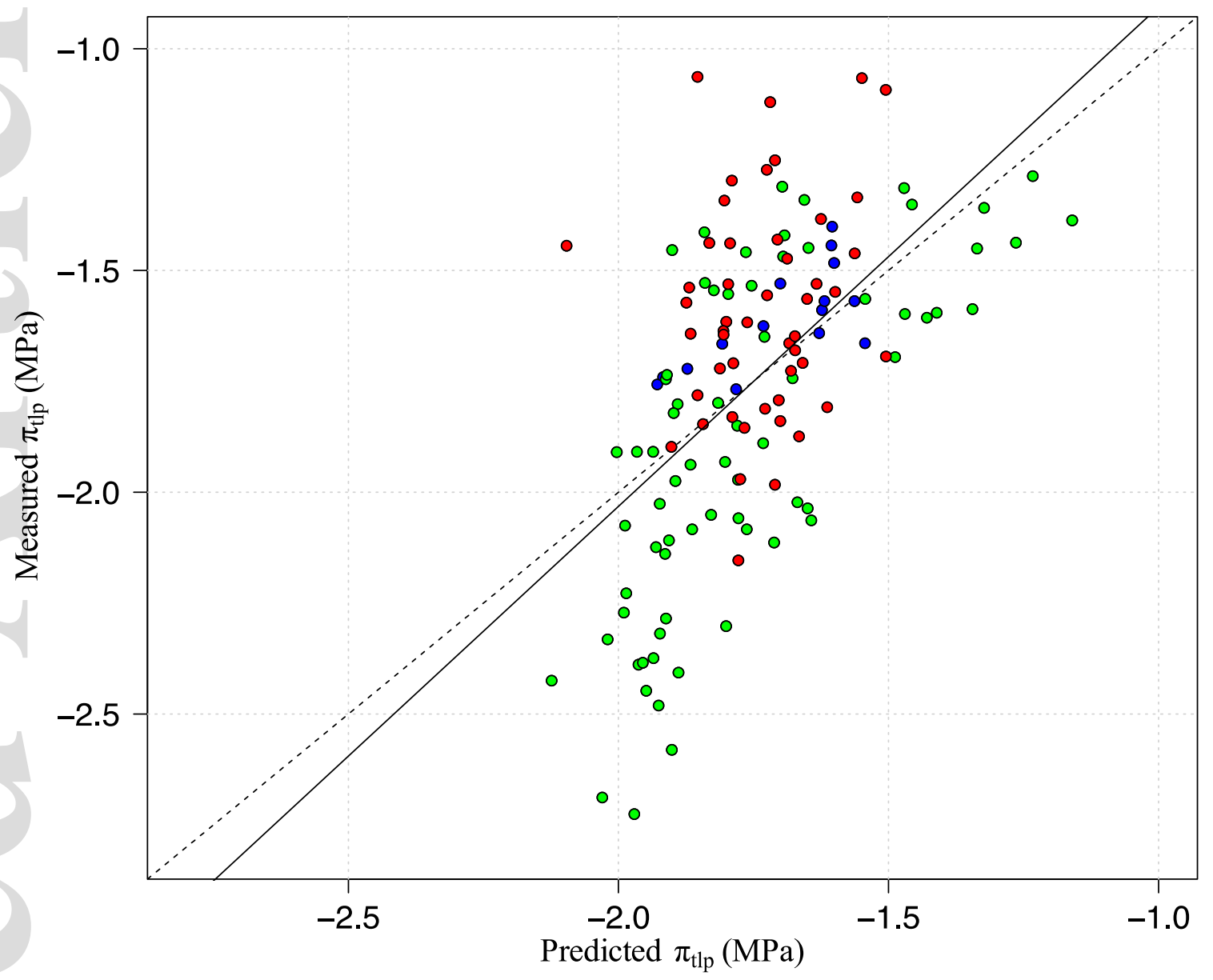

This article is protected by copyright. All rights reserved 